\title{
Characterization and selection of upland rice germplasm under low and high soil phosphorous (p) and nitrogen $(n)$ environments
}

\author{
Kimani J. M. ${ }^{1 *}$, Tongoona P. ${ }^{2}$ and Derera J. ${ }^{2}$ \\ ${ }^{1}$ Kenya Agricultural Research Institute - Mwea Tebere, P.O. Box 298-10300, Kerugoya, Kenya. \\ ${ }^{2}$ African Centre for Crop Improvement, School of Agricultural Sciences and Agribusiness, Faculty of Science and \\ Agriculture, University of KwaZulu-Natal, Republic of South Africa.
}

Accepted 21 October, 2011

\begin{abstract}
A total of 389 accessions and a local cultivar Duorado precoce were evaluated in a simple $30 \times 13$ alpha lattice design with two replications under four experimental environments ( $N^{-} \mathbf{P}^{-}$, no $\mathbf{N}$ or $\mathrm{P}$ application; $\mathrm{N}^{-} \mathrm{P}^{+}, \mathrm{P}$ applied; $\mathrm{N}^{+} \mathrm{P}^{-}, \mathrm{N}$ applied and $\mathrm{N}^{+} \mathrm{P}^{+}$, both $\mathrm{N}$ and $\mathrm{P}$ applied) at the rate of $60 \mathrm{~kg} \mathrm{P}$ and $90 \mathrm{~kg} \mathrm{~N} \mathrm{ha}^{-1}$. Data was recorded on Days to heading, anthesis and maturity (days), $\mathbf{P}$ and $\mathbf{N}$ tolerance, plant height $(\mathrm{cm})$, above ground biomass (g), number of panicles (absolute numbers per ten plants), days to maturity (days), 1000 grain weight $(\mathrm{g})$, and grain yield $\left(\mathrm{kg} \mathrm{ha}^{-1}\right)$. The genotypes and environments were highly significant for all the traits studied. The degree of genetic determination $\left(\mathrm{H}^{2}\right)$ ranged from $6.8 \%$ for $\mathrm{P}$ tolerance to $36.5 \%$ for above ground biomass. The phenotypic coefficient of variation of genotypes ranged from $14.3 \%$ for days to maturity to $159.7 \%$ for top biomass. The genetic advance (GA) ranged from 0.2 for phosphorous tolerance to 1080.5 for grain yield, while the genetic advance expressed as percent of the mean was $5.7 \%$ for days to maturity and $\mathbf{8 7 . 9} \%$ for top biomass. The top biomass seems to be highly heritable trait and simple phenotypic selection is possible. The ten characters studied had wide variability under the four environments with days to maturity ranging from 188 for genotype ARCCU1Fa1-L4P3-HB under $\mathrm{N}^{+} \mathrm{P}^{+}$to 177 for genotype CT16333(1)-CA-1-M under N-Pcondition. The highest yielding genotype was CT16328-CA-18-M under N-P- with $5916 \mathrm{~kg} \mathrm{ha}^{-1}$. The germplasm showed variability for low soil $\mathrm{N}$ and $\mathrm{P}$ adaptation, and hence improvement was possible to take advantage of the vast unexploited upland environments for increased rice productivity. There was high variability in the genotypes to warrant rice improvement for yield.
\end{abstract}

Key words: Soil fertility, genetic advance, genotypes, heritability, Kenya, rice.

\section{INTRODUCTION}

In Kenya, rice is third most important staple food crop after maize and wheat, but it is grown under low fertility conditions resulting in low yields. Rice forms part of the diet and source of employment and income for both urban and rural populations. The domestic production oscillates between 45 to $80,000 \mathrm{MT}$, while total national consumption is well above $300,000 \mathrm{MT}$ (Rosemary et al., 2010). This creates a deficit of more than 250,000 MT that has to be met through imports. The over $80 \%$ deficit

\footnotetext{
*Correspondence author. E-mail: kimanijm69@gmail.com.
}

cost the country about USD 90 million in imports from Pakistan, China, India and Vietnam (Monem, 2005). The current state of low productivity of the rice sector is worrisome, the rate of consumption is growing at $12 \%$ when the domestic production has stagnated for the last couple of years (Mo, 2009). In Kenya, rice breeding work has been lacking and no home grown varieties have therefore, been developed. The current varieties are from accessions from other parts of the world, of which the production condition are different to the local production environments. No attempts have been made to breed for local genotypes tailored to perform under the prevailing poor soil fertility conditions that are rampant. The existing 
materials were acquired years ago, and their acquisition criteria have since changed and thus these materials are less relevant. The breeding methodologies must be embraced that encompass the full participation of end users of the technology being developed, use of the appropriate germplasm with the desirable genes that convey the traits of interest. Further, use of breeding methodologies in terms of mating designs and evaluation or environmental designs together with the use of proper data analytical software and interpretation of the results is vital if the desired result are to be realized (Atlin et al., 2006a; Christiansen and Lewis, 1982; De-Datta et al., 2002; Fasoula and Fasoula, 1997; Fasoula and Fasoula, 2000; Fukai et al., 1999)

The development of upland rice varieties that have the end user traits can greatly contribute to higher adoption rate (Poussin et al., 2006). This, coupled by the fact that upland rice is unexploited despite the gigantic potential it has in terms of land availability and ease of cultivation, can unlock the current status of deficit rice production (Mo, 2009). However, the cultivars lack low soil $\mathrm{N}$ and $\mathrm{P}$ tolerance. The genetics and variances contributing to the traits of interest should be determined and to make correct decisions regarding the varieties being used as parents and the progenies (Allard, 1960; Borojevi'c, 1990; Falconer, 1989; Simmonds and Smartt, 1999). If the genes conferring a sought trait are not present in the breeding materials used in a programme, even if all the other steps are correct; this is a total waste of time as no positive results can be realized (Ceccarelli, 1994; Presterl et al., 2003). Every effort should be made to ensure evaluation stress is present and that the 'cooking pot' has all the desirable ingredients for the sought end product technology to be of any value to the users (Banziger et al., 2006; Edmeades et al., 1997). It is for these reasons that germplasm was acquired and characterization carried out for the breeding program in Kenya. The rationale of the study was to evaluate and select adapted promising genotypes with desirable genes for low soil $\mathrm{P}$ and $\mathrm{N}$ from the broad germplasm accession for hybridization with the local cultivars. The specific objectives were then to characterize the accessions for various agronomic traits under local conditions and different soil $\mathrm{P}$ and $\mathrm{N}$ conditions; determine variation and genetic parameters responsible for performance under low and high soil $\mathrm{P}$ and $\mathrm{N}$ conditions; and identify adapted lines from the accessions to be used as parents in the breeding programme.

There is a strong need to acquire new accessions with the desirable qualities and traits, and evaluate them for adaptability under local production environments before selecting some to supplement the few existing one for breeding work. The need for genetic base broadening germplasm lead to acquisition of 390 lines that were requested on their tolerance to low soil $\mathrm{N}$ and $\mathrm{P}$, good grain quality and drought tolerant. These were acquired in order to introduce gene systems missing in the local cultivars and hence their adaptation and characterization was necessary in order to determine their suitability and performance under Kenyan conditions. This also allowed selection of those adapted lines with the sought traits for use in hybridization programme to improve the local cultivars. The early maturing, well adapted lines to low soil $\mathrm{N}$ and $\mathrm{P}$ and with desirable grain qualities were the main traits sought.

\section{MATERIALS AND METHODS}

\section{Study location}

KARI- Mwea Tebere (National Rice and Fiber Research Centre (NRFRC)) is located in Mwea Division, Kirinyaga South District, and Central Province, Kenya. It lies on Latitude $00^{\circ} 37^{\prime} \mathrm{S}$ and Longitude $37^{\circ} 20^{\prime} \mathrm{E}$ at an elevation of $1159 \mathrm{~m}$ above sea level (MASL). The average rainfall is about $850 \mathrm{~mm}$ with a range of 500 to $1250 \mathrm{~mm}$ divided into long rains (March to June with an average of $450 \mathrm{~mm}$ ) and short rains (Mid-October to December with an average of 350 $\mathrm{mm}$ ). The rainfall is characterized by uneven distribution in total amounts, time and space. The temperature ranges from 15.6 to $28.6^{\circ} \mathrm{C}$ with a mean of about $22^{\circ} \mathrm{C}$. The soil is a nitosol, deep, well drained dusky-red to dark reddish-brown, friable clay with low fertility (Kimani, 2010).

\section{Germplasm, experiment layout and trial management}

Germplasm was procured from different regions and it consisted of 314 lines from CIAT Columbia, 75 lines from Africa Rice Centre and the local check Dourado precoce. The four experimental environments were blocks that had no $\mathrm{P}$ and $\mathrm{N}$ applied $\left(\mathrm{N}^{-} \mathrm{P}^{-}\right), \mathrm{P}$ applied only $\left(\mathrm{NP}^{+}\right), \mathrm{N}$ applied only $\left(\mathrm{N}^{+} \mathrm{P}^{-}\right)$and both $\mathrm{N}$ and $\mathrm{P}$ applied $\left(\mathrm{N}^{+} \mathrm{P}^{+}\right)$. The source of $\mathrm{N}$ and $\mathrm{P}$ were inorganic fertilizers calcium ammonium nitrate $(\mathrm{CAN})$ and triple super phosphate (TSP-(CaHPO $\left.\left.{ }_{4}\right)-32.5 \%\right)$, respectively. The $\mathrm{P}$ and $\mathrm{N}$ were applied as basal applications in the designated block at the rate of $60 \mathrm{~kg} \mathrm{P} \mathrm{ha}^{-1}$ and $90 \mathrm{~kg} \mathrm{~N} \mathrm{ha}^{-1}$. The $\mathrm{P}$ was applied as basal during planting; while $\mathrm{N}$ was applied in two splits each $45 \mathrm{~kg} \mathrm{~N} \mathrm{ha}^{-1}$ at planting and at panicle initiation stage. The soil was sampled in the 0 to $30 \mathrm{~cm}$ top soil layer over the experimental blocks. It was sampled in both diagonals at the four corners of the block, at the middle, between the corners, and between the middle of diagonals and corners making a total of 17 samples. These samples were analyzed separately and since they had almost the same values, these were composited and averaged. The soil analysis was carried out at JomoKenyatta University of Agriculture and Technology (JKCUAT) and had the properties indicated in Table 1.

The three hundred and ninety (390) accessions were planted in an alpha lattice design arrangement as $30 \times 13$ replicated twice on 29th November, 2007. Fertilizer level was applied to the block, while genotypes were planted in the block. The experimental plot was $0.75 \mathrm{~m}^{2}$ consisting of 34 plants. The row to row and plant to plant spacing was $15 \mathrm{~cm}$. Two seeds were sown per hill and later thinned to one. Normal cultural practices like weeding, spraying and harvesting were carried out manually.

\section{Data collection}

Data collection followed the established standards for rice (IRRI, 2002) on the following traits; days to heading (days), days to anthesis (days), $\mathrm{P}$ tolerance (scale, 1 to 5 ), $\mathrm{N}$ tolerance (scale, 1 to 5 ), plant height $(\mathrm{cm})$, top biomass $(\mathrm{g})$, number of panicles for 10 plants (absolute numbers), days to maturity (days), 1000 grain wt $(\mathrm{g})$, and grain weight ha ${ }^{-1}(\mathrm{~kg})$. The nitrogen tolerance scale of 1 to5 
Table 1. Soil properties at KARI Mwea-Tebere location indicating the soil characteristics.

\begin{tabular}{lccccc}
\hline Parameter & Value & High & Medium & Low & Very low \\
\hline $\mathrm{pH}_{1: 1}$ & 5.53 & & & & \\
ECe (Electrical conductivity) & 0.11 & & & & \\
$\% \mathrm{~N}$ & 0.16 & $>0.25$ & $0.12-0.25$ & $0.05-0.12$ & $<0.05$ \\
Available P (ppm) & 1.35 & $>18$ & $10-17$ & $5-9$ & $<5$ \\
Extractable-Zn (ppm) & 1.65 & & & & \\
Extractable-Cu (ppm) & 8.52 & & & & \\
Extractable-Mn (ppm) & 360 & & & & \\
Extractable-Fe (ppm) & 379 & & & & \\
\hline
\end{tabular}



Figure 1. A leaf colour chart used to evaluate genotypes for nitrogen tolerance.

was used to measure leaf colour intensity which is related to leaf $\mathrm{N}$ status (Shukla et al., 2004) (Figure 1). The value on LCC that matched the leaf colour was recorded and if the leaf colour fell between two LCC shades, the mean value was taken. This is a non-destructive method and readings were taken under the shade of the body to shield the sunlight as this would affect the colour reading. Plants that were $\mathrm{N}$ tolerant were given a score of one (but in LCC its 5) and those that were least tolerant were given a score of five (but in LCC its 1).

The $\mathrm{P}$ tolerant scale was developed based on the following visual parameters of $P$ deficiency that include; stunted growth, dull-green or blue-green colour, possible purple coloration on some part of the plant, reduced flowering, delayed maturity, leaf tips look burnt, followed by older leaves turning a dark green, and reddish-purple colour. The most $\mathrm{P}$ tolerant plants were rated one and these had normal vigorous growth without deficiency symptoms, while the least tolerant ones were rated five and these had high deficiency symptoms.

For the agronomic traits, ten plants were randomly selected for data collection and the early maturing lines were tagged with a different colour code of netting string, one colour per week for three weeks. The top biomass was taken from an area of $0.75 \mathrm{~m}^{2}$ in grams (g) by cutting the culms at the ground level with a sickle. The harvested culms without panicles were dried to constant moisture and then weighed and data recorded. Plant height was measured from soil surface to the tip of the tallest panicle (awns excluded) (IRRI, 2002). Days to maturity were counted as number of days from seeding to grain ripening. One thousand seeds weight was measured at $14 \%$ moisture content using a precision balance. The yield was taken as the weight of unhulled grains harvested from an area of $0.75 \mathrm{~m}^{2}$ and then converted to $\mathrm{kg} \mathrm{ha}^{-1}$ at $14 \%$ moisture content.

\section{Data analysis}

The analysis of variance (ANOVA) was performed according to Gomez and Gomez (1884) using GenStat statistical package version 12 (Payne et al., 2009). The statistical model was $Y_{\mathrm{ijk}}=\mu+$ $\alpha_{i}+\beta_{j}+\varepsilon_{k}+\alpha \varepsilon_{i k}+\epsilon_{i j k}$; where the term $Y_{i j k}$ is the observed value of $i^{\text {th }}$ genotype $(I=1$ to 390$)$ in $j^{\text {th }}$ replicate $(j=1$ to 2$)$ for the $k^{\text {th }}$ experimental environment, $\mu$ is the grand mean of the variable; $\alpha_{i}$ is the treatment effect for the $i^{\text {th }}$ genotype, $\beta_{j}$ is the block effect for $j^{\text {th }}$ block; $\varepsilon_{k}$ is the experimental effect for the $k^{\text {th }}$ experimental environment, $\alpha \varepsilon_{i k}$ is the interaction term of $i^{\text {th }}$ genotype in $k^{\text {th }}$ experimental environment and $\epsilon_{\mathrm{ijk}}$ is the random error associated with the $Y_{\mathrm{ijk}}$ experimental unit.

The genetic variances for the various traits were calculated following the method of Johnson et al. (1955) and Karim et al. (2007). Genetic parameters were calculated as follows:

(i) Genetic variance $(\mathrm{Vg})=$ (genotypic mean squares - error mean squares)/number of replicates.

(ii) Phenotypic variance $(\mathrm{Vp})=$ genotypic mean squares + error mean squares.

(iii) The genotypic coefficient of variation $(C V G)=(\sqrt{ } \mathrm{gg} / \mathrm{grand}$ mean $)^{*} 100$.

(iv) Genetic advance $(G A)$ estimates $=\left(\sqrt{ } V p^{*} H^{2}\right)^{*} k$; where $k=2.06$ and it is the selection differential expressed in standard deviations (Karim et al., 2007), that assumed that $5 \%$ of the individual plants were selected from the population (Kearsey and Pooni, 1996). 
Table 2. Mean squares and genetic parameters for ten rice traits across the four soil experimental environments.

\begin{tabular}{|c|c|c|c|c|c|c|c|c|c|c|c|}
\hline Traits & & $\begin{array}{l}\text { Days to } \\
\text { heading } \\
\text { (days) }\end{array}$ & $\begin{array}{l}\text { Days to } \\
\text { anthesis } \\
\text { (days) }\end{array}$ & $\begin{array}{c}\text { Phosphorous } \\
\text { tolerance } \\
\text { (scale 1-5) }\end{array}$ & $\begin{array}{l}\text { Nitrogen } \\
\text { tolerance } \\
\text { (scale 1-5) }\end{array}$ & $\begin{array}{l}\text { Plant } \\
\text { height } \\
\text { (cm) }\end{array}$ & $\begin{array}{c}\text { Top } \\
\text { biomass } \\
\text { (g) }\end{array}$ & $\begin{array}{c}\text { Number of } \\
\text { panicles } \\
\text { (numbers) }\end{array}$ & $\begin{array}{l}\text { Days to } \\
\text { maturity } \\
\text { (day) }\end{array}$ & $\begin{array}{l}1000 \text { grain } \\
\text { weight } \\
\text { (g) }\end{array}$ & $\begin{array}{c}\text { Yield } \\
\left(\text { kg ha-1) }^{-1}\right.\end{array}$ \\
\hline Source & DF & & & & & & & & & & \\
\hline Replication & 1 & 752.6 & 435 & 4.313 & 86.0013 & 5215.5 & 169945 & 37773 & 435 & 183.51 & 9483000.0 \\
\hline Genotype & 389 & $507^{\star * *}$ & $494.1^{\text {*** }}$ & $1.469^{\star * *}$ & $1.959^{* * *}$ & $454.6^{* * *}$ & $1002130^{* * *}$ & $3989^{* * *}$ & $494.1^{* * *}$ & $57.25^{\star * *}$ & $4346000^{* * *}$ \\
\hline Experimental environment & 3 & $20595.9^{* * *}$ & $18058.2^{* * *}$ & $138.066^{* * *}$ & $74.7436^{\star * *}$ & $3481.9^{* * *}$ & $1674391^{* * *}$ & $39612^{* * *}$ & $18058.2^{* * *}$ & $5022.78^{* * *}$ & $17000000^{* * *}$ \\
\hline Genotype experimental environment & 1167 & $216.1^{\text {*** }}$ & $214.6^{* * *}$ & $1.028^{\text {ns }}$ & $0.702^{\mathrm{ns}}$ & $133.4^{\mathrm{ns}}$ & $181403^{* * *}$ & 960 & $214.6^{* * *}$ & $31.21^{\mathrm{ns}}$ & $1305000^{\text {ns }}$ \\
\hline Residual & 1559 & 178.4 & 174.7 & 1.119 & 0.6902 & 133.7 & 157061 & 1051 & 174.7 & 40.24 & 1173000.0 \\
\hline Mean & & 132.4 & 137.5 & 2.0 & 3.1 & 81.5 & 674.1 & 54.5 & 180.5 & 16.4 & 3639.0 \\
\hline Genotypic variance $(\mathrm{Vg})$ & & 164.3 & 159.7 & 0.2 & 0.6 & 160.5 & 422534.5 & 1469.0 & 159.7 & 8.5 & 1586500.0 \\
\hline Phenotypic variance $(V p)$ & & 685.4 & 668.8 & 2.6 & 2.6 & 588.3 & 1159191.0 & 5040.0 & 668.8 & 97.5 & 5519000.0 \\
\hline Coeficient of variation of genotypes (CVG) & & 17.0 & 16.2 & 60.6 & 45.5 & 26.2 & 148.5 & 115.9 & 12.3 & 46.1 & 57.3 \\
\hline Coeficient of variation of phenotypes (CVP) & & 19.8 & 18.8 & 80.5 & 52.9 & 29.8 & 159.7 & 130.3 & 14.3 & 60.2 & 64.6 \\
\hline Broad sense heritability $\left(\mathrm{H}^{2}\right)$ & & 23.9 & 23.9 & 6.8 & 23.9 & 27.3 & 36.5 & 29.1 & 23.9 & 8.7 & 28.7 \\
\hline Genetic advance (GA) & & 10.4 & 10.3 & 0.2 & 0.6 & 10.7 & 592.5 & 33.0 & 10.3 & 1.6 & 1080.5 \\
\hline Genetic advance as $\%$ of mean (GAM) & & 7.9 & 7.5 & 10.5 & 21.1 & 13.1 & 87.9 & 60.6 & 5.7 & 10.0 & 29.7 \\
\hline
\end{tabular}

${ }^{* * *}$ Significant at $p<0.001$, ns Non significant at $p<0.05$.

(vii) The percent genetic advance of the mean (GAM) = (GA/grand mean)*100.

\section{RESULTS}

\section{Genetic components}

The results of analysis of variance components showed that genotypic differences were very highly significant $(p<0.001)$ for all the traits studied. This was also the case with experimental environments (Table 2). However, the interaction of genotypes by experimental environments was not significant $(p>0.05)$ except for days to heading $(\mathrm{DH})$, days to anthesis (DA), top biomass (TB) and days to maturity (DM).

The lowest $\mathrm{Vg}$ was for phosphorous tolerance (PT) and the highest for yield and this was also the case for $V p$, except that nitrogen tolerance (NT) had the same Vp (Table 2). The CVG was lowest for days to maturity and highest for top biomass (TB), this was the same case for CVP. The ranges for CVG and CVP were 12.3 to 148.5 and 14.3 to $159.7 \%$, respectively. Broad sense heritability $\left(\mathrm{H}^{2}\right)$ estimates were highest for TB $(36.5 \%)$ and lowest for PT (6.8\%). The days to heading, days to anthesis, days to maturity and NT had a $\mathrm{H}^{2}$ value of $23.9 \%$. The genetic advance (GA) had the lowest value for phosphorous tolerance (PT) of 0.2 but the value was large for yield at 1080.5 . The genetic advance as a percent of mean (GAM) was lowest for days to maturity (DM) but highest for top biomass (TB). The values for $\mathrm{H}^{2}, \mathrm{GA}$ and $\mathrm{GAM}$ were generally low except for top biomass and yield.

\section{Genotypic performance under the four experimental environments}

Different genotypes performed differently and their ranks varied under the four experimental environments. The earliest line to head was 39 (Caiapo) under $\mathrm{N}-\mathrm{P}+$ fertility condition (Table 3 ). It was the earliest in the other soil $\mathrm{N}$ and $\mathrm{P}$ fertility conditions except under N-P-. Some genotypes however, were poorly adapted like 272 (CT16345-CA-12-M) and 303 (CT16350-CA-27-M) which headed in 167 and 160 days, respectively.

Two lines 362 (WAB 450-I-B-P-38-HB - NERICA1) and 96 (CT16317-CA-4-M) were selected as parents for crossing block appeared among the top ten in days to heading, anthesis and maturity. Caiapo (39) still was the earliest in days to 
anthesis at 73 days under the $\mathrm{N}^{-} \mathrm{P}^{+}$condition. The genotypes ranked differently for days to heading, anthesis and maturity. Two parents 362 (WAB 450-I-B-P-38-HB) and 96 (CT16317-CA-4-M) appeared among the top ten best genotypes. Line 272 (CT16345-CA-12-M) had its anthesis period being the latest at 172 days under $\mathrm{N}^{+} \mathrm{P}^{+}$. The earliest line 39 (Caiapo) matured in 116 days under $\mathrm{N}^{-} \mathrm{P}^{+}$ experimental condition, but under $\mathrm{N}^{+} \mathrm{P}^{-}$it flowered in 136 days but still the earliest under this condition. The top ten lines in maturity displayed change of ranks under the four fertility conditions. Line 272 (CT16345-CA-12-M) matured latest in 215 days under $\mathrm{N}^{+} \mathrm{P}^{+}$condition. Line 159 (CT16329-CA-10-M) ranked top for number of panicles for 10 plants with 150 and 178 panicles under $\mathrm{N}^{+} \mathrm{P}^{-}$and $\mathrm{N}^{+} \mathrm{P}^{+}$fertility conditions, respectively. However, it did not appear among top ten under $\mathrm{N}^{-} \mathrm{P}^{-}$and $\mathrm{N}^{-} \mathrm{P}^{+}$conditions, where line 242 (CT16340-CA-13-M) and 225 (CT16337CA-7-M) were ranked at the top, respectively. Line 17 (ARCCU3Fa12-L 11 P82-HB) had the lowest number of panicles.

Line 6 (ARCCU1 Fa5-L4P1-HB) was ranked among the top 3 under N-P- and N-P+ fertility condition, while two lines, 96 (CT16317-CA-4-M) and 195 (CT16333(2)-CA18-M) were among the top ten in phosphorous tolerance under $\mathrm{N}+\mathrm{P}$ - and $\mathrm{N}+\mathrm{P}+$ fertility conditions (Table 4). Line 168 (CT16330(1)-CA-2-M) was the worst in terms of phosphorous tolerance under N-P- fertility condition. Line 170 (CT16330(1)-CA-4-M) had consistent nitrogen tolerance except under $\mathrm{N}-\mathrm{P}+$ where it was not among the top ten lines. Lines 6 (ARCCU1 Fa5-L4P1-HB) and 167 (CT16330(1)-CA-15-M) showed consistent performance by appearing top ten under $\mathrm{N}-\mathrm{P}+$ and $\mathrm{N}^{+} \mathrm{P}^{-}$fertility conditions. Line 27 (ARCCU3Fa3-L7P1-HB) consistently displayed superior nitrogen tolerance ranking top under $\mathrm{N}+\mathrm{P}+$ and top three under $\mathrm{N}^{-} \mathrm{P}^{+}$and $\mathrm{N}^{+} \mathrm{P}^{-}$experimental conditions. However, there was great variability in nitrogen tolerance as indicated by varied genotypes appearance or rankings for both top 10 best and worst cases. Lines 39 (Caiapo) and 267 (CT16344-CA-3-M) had the worst nitrogen tolerance under $\mathrm{N}^{-} \mathrm{P}^{+}$fertility condition. The 1000 seed weight had extreme variability in that no single line appeared to be consistent in performance across the four fertility experimental conditions (Table 4). Only one parent 76 (CT16313-CA-19-M) appeared among the top ten lines for best performers under $\mathrm{N}+\mathrm{P}$ - condition. Line 362 (WAB 450-I-B-P-38-HB-NERICA1) appeared among the worst performers under soil $\mathrm{N}+\mathrm{P}+$ environmental condition.

Lines 182 (CT16333(1)-CA-20-M) and 76 (CT16313-CA$19-\mathrm{M})$ selected as parents were among the best ten yielders under $\mathrm{NP}^{-}$and $\mathrm{NP}^{+}$fertility condition. Line 222 (CT16337-CA-3-M) was ranked top under $\mathrm{N}+\mathrm{P}$ - and also appeared among the best ten under $\mathrm{N}+\mathrm{P}+$ fertility environments. Line 360 (WAB 450-I-B-P-20-HB) ranked number 3 under $\mathrm{N}-\mathrm{P}+$ and $\mathrm{N}+\mathrm{P}+$ fertility conditions thus showing some consistency. This was also the case for line 378 (WAB 905-B-4A 1.1). Line 370 had superior performance under $\mathrm{N}^{-} \mathrm{P}^{-}$and $\mathrm{N}^{+} \mathrm{P}^{+}$experimental fertility envi- ronments thus indicating adaptability and responsiveness to fertility environments. Line 39 (Caiapo) and 314 (CT16350-CA-7-M) had poor performance, especially for Caiapo that was early maturing and thus used as parent for earliness.

The plant height had varied performance under the four fertility conditions with many of the lines failing to show consistency (Table 5). The line 76 (CT16313-CA-19-M) that was selected as parent appeared among the top ten lines under $\mathrm{N}+\mathrm{P}$ - condition. Line 221 (CT16337-CA-3-M) had consistency in its performance under $\mathrm{N}^{+} \mathrm{P}^{-}$and $\mathrm{N}^{+} \mathrm{P}^{+}$ fertility condition, a case displayed by line 175 (CT16331CA-8-M) under $\mathrm{NP}^{+}$and $\mathrm{N}^{+} \mathrm{P}^{-}$condition. Line 195 (CT16333(2)-CA-18-M) selected as parent appeared among the worst ten in height under $\mathrm{N}+\mathrm{P}+$ condition.

Genotypes performance for biomass were also widely varied with line 96 (CT16317-CA-4-M) appearing among the best top ten under $\mathrm{N}^{+} \mathrm{P}^{-}$condition. Genotype 175 (CT16331-CA-8-M) had consistent performance under three experimental fertility conditions, ranking top under $\mathrm{NP}^{+}$and $\mathrm{N}^{+} \mathrm{P}^{+}$conditions. The highest biomass $(3888.5 \mathrm{~g})$ was associated with line 272 (CT16345-CA-12-M) under $\mathrm{N}^{-} \mathrm{P}^{-}$fertility condition, which also appeared under $\mathrm{N}^{-} \mathrm{P}^{+}$ condition. The worst line was 345 (CT16356(1)-CA-7-M) having $12.5 \mathrm{~g}$ under $\mathrm{N}^{-} \mathrm{P}^{-}$fertility condition.

\section{Scatter plots and histograms for days to maturity and yield}

From the display of scatter plot for yield versus days to maturity, Figure 2, line 378 (WAB 905-B-4A 1.1) was the best in terms of yield and earliness among the 25 earliest lines under N-P- conditions. It was followed by 368 (WAB 880-1-38-20-15-P2-HB) and 381 (WAB 919-72-4-1-HB). Line 291 (CT16346-CA-8-M) was the most undesirable as it had low yields and very late in maturity. The scatter plot under soil N-P+ had genotypes 245 (CT16340-CA-9M), 277 (CT16345-CA-4-M) and 364 (WAB 450-I-B-P-91HB) being early and high yielding (Fig. 3). Genotype 74 (CT16313-CA-15-M) was the latest among the best twenty five genotypes and its yield was around the mean. Genotype 361 (WAB 450-I-B-P-28-HB) although was around the mean in maturity, it had the lowest yield. Line 340 although it was the earliest its yield potential was around the mean. Figure 4 displays the scattering of the best twenty five genotypes of which line 222 (CT16337CA-3-M) was the highest yielding and also its maturity was below the mean. However line 353 (O. glaberrima) although high yielding, it was late second to line 81 (CT16315(1)-CA-1-M) which was the second lowest in terms of yield. The earliest line was 96 (CT16317-CA-4$\mathrm{M})$ which was within the early and high yielding quadrant. Line 102 (CT16319-CA-13-M) was the lowest yielder but it was early hence not a desirable genotype. The majority of the genotypes tended to be late but were high yielding. The scatter plot of genotypes under $\mathrm{N}+\mathrm{P}+$ experimental fertility conditions by days to maturity versus yield displayed line 356 (WAB 450-11-1-P31-1-HB) as the most 
Table 3. The mean values of $\mathrm{DH}, \mathrm{DA}, \mathrm{DM}$ and NP traits for the 10 best and worst genotypes under four environments (N-P-, N-P+, N+P- and N+P+).

\begin{tabular}{|c|c|c|c|c|c|c|c|c|c|c|c|c|c|c|c|c|}
\hline \multirow{2}{*}{ Parameter } & \multicolumn{8}{|c|}{ Days to heading (days) } & \multicolumn{8}{|c|}{ Days to maturity (days) } \\
\hline & Lines & N-P- & Lines & N-P+ + & Lines & $N^{+} P-$ & Lines & $\mathrm{N}^{+} \mathrm{P}^{+}$ & Lines & N-P- & Lines & $\mathrm{N} \cdot \mathrm{P}^{+}$ & Lines & $N^{+} P-$ & Lines & $\mathrm{N}^{+} \mathrm{P}^{+}$ \\
\hline \multirow{10}{*}{ Top ten lines } & 368 & 92.5 & 39 & 68.5 & 39 & 88.0 & 39 & 76.5 & 378 & 139.5 & 39 & 116.0 & 39 & 135.5 & 39 & 126.0 \\
\hline & 378 & 92.5 & 362 & 83.0 & 356 & 90.0 & 355 & 90.0 & 368 & 142.0 & 362 & 129.5 & 356 & 137.5 & 355 & 136.5 \\
\hline & 43 & 96.0 & 356 & 93.5 & 96 & 100.0 & 374 & 95.5 & 381 & 144.0 & 285 & 142.0 & 96 & 149.5 & 374 & 144.5 \\
\hline & 381 & 96.5 & 285 & 94.0 & 362 & 101.5 & 356 & 98.0 & 43 & 145.0 & 356 & 142.5 & 362 & 150.0 & 356 & 148.5 \\
\hline & 45 & 99.5 & 382 & 96.0 & 212 & 109.0 & 68 & 104.5 & 45 & 151.0 & 382 & 142.5 & 212 & 156.0 & 388 & 152.5 \\
\hline & 49 & 101.0 & 328 & 98.0 & 355 & 109.5 & 388 & 104.5 & 212 & 151.0 & 328 & 144.5 & 355 & 156.0 & 68 & 153.5 \\
\hline & 356 & 102.0 & 291 & 98.5 & 371 & 110.0 & 362 & 109.0 & 44 & 151.5 & 371 & 146.5 & 371 & 157.5 & 362 & 155.5 \\
\hline & 212 & 103.5 & 160 & 99.5 & 242 & 111.5 & 314 & 111.5 & 92 & 151.5 & 41 & 148.5 & 388 & 159.0 & 16 & 159.0 \\
\hline & 58 & 105.0 & 371 & 99.5 & 388 & 112.0 & 16 & 112.0 & 49 & 153.0 & 376 & 148.5 & 2 & 159.5 & 314 & 159.5 \\
\hline & 277 & 105.0 & 376 & 99.5 & 2 & 112.5 & 15 & 114.5 & 194 & 153.5 & 291 & 149.0 & 54 & 160.0 & 385 & 161.5 \\
\hline \multirow{10}{*}{ Bottom ten lines } & 33 & 148.5 & 37 & 151.5 & 83 & 154.0 & 104 & 162.0 & 68 & 195.5 & 309 & 199.5 & 83 & 202.0 & 89 & 210.0 \\
\hline & 68 & 148.5 & 62 & 151.5 & 7 & 154.5 & 185 & 162.0 & 24 & 196.0 & 37 & 200.0 & 155 & 202.0 & 124 & 210.0 \\
\hline & 138 & 148.5 & 133 & 152.0 & 243 & 155.0 & 253 & 162.0 & 33 & 196.0 & 133 & 200.0 & 7 & 202.5 & 155 & 210.0 \\
\hline & 297 & 148.5 & 24 & 156.0 & 342 & 155.5 & 259 & 162.0 & 297 & 196.5 & 24 & 204.0 & 58 & 204.0 & 253 & 210.0 \\
\hline & 307 & 149.3 & 82 & 159.0 & 58 & 156.5 & 329 & 162.0 & 32 & 197.5 & 253 & 206.5 & 342 & 204.0 & 255 & 210.0 \\
\hline & 12 & 149.5 & 196 & 159.0 & 169 & 157.0 & 86 & 162.5 & 307 & 197.5 & 82 & 207.0 & 169 & 205.0 & 259 & 210.0 \\
\hline & 24 & 149.5 & 253 & 159.0 & 82 & 159.0 & 89 & 162.5 & 12 & 198.5 & 332 & 207.0 & 82 & 206.0 & 329 & 210.0 \\
\hline & 32 & 150.0 & 294 & 159.0 & 192 & 159.0 & 186 & 162.5 & 298 & 199.0 & 303 & 207.0 & 192 & 206.5 & 104 & 210.5 \\
\hline & 301 & 151.5 & 387 & 159.0 & 260 & 159.0 & 255 & 163.0 & 301 & 199.0 & 196 & 207.5 & 260 & 206.5 & 186 & 210.5 \\
\hline & 10 & 153.0 & 303 & 159.5 & 271 & 159.0 & 272 & 166.5 & 10 & 201.5 & 387 & 207.5 & 271 & 207.5 & 272 & 215.0 \\
\hline \multirow[t]{2}{*}{ Mean } & & 128.2 & & 139.0 & & 128.5 & & 133.9 & & 176.9 & & 176.8 & & 181.4 & & 187.0 \\
\hline & s.e.d. & I.s.d. & & & & & & & s.e.d. & I.s.d. & & & & & & \\
\hline Genotype & 6.68 & 13.1 & & & & & & & 6.61 & 13.0 & & & & & & \\
\hline Experimental environment & 0.68 & 1.3 & & & & & & & 0.67 & 1.3 & & & & & & \\
\hline \multirow{4}{*}{$\begin{array}{l}\text { Genotype*experimental environment } \\
\text { CV\% }\end{array}$} & 13.36 & 26.2 & & & & & & & 13.22 & 25.9 & & & & & & \\
\hline & 10.10 & & & & & & & & 7.30 & & & & & & & \\
\hline & \multicolumn{8}{|c|}{ Days to anthesis (days) } & & \multicolumn{7}{|c|}{ Number of panicles (numbers) } \\
\hline & Lines & N-P. & Lines & $\mathbf{N} \cdot \mathbf{P}^{+}$ & Lines & $\mathrm{N}+\mathrm{P}-$ & Lines & $\mathbf{N}^{+} \mathbf{P}^{+}$ & Lines & N-P- & Lines & $\mathrm{N} \cdot \mathrm{P}^{+}$ & Lines & $\mathrm{N}+\mathrm{P}-$ & Lines & $\mathrm{N}^{+} \mathrm{P}^{+}$ \\
\hline \multirow{4}{*}{ Top ten lines } & 378 & 96.5 & 39 & 73.0 & 39 & 92.5 & 39 & 83.0 & 242 & 133.0 & 225 & 263.0 & 159 & 149.5 & 159 & 177.5 \\
\hline & 368 & 99.0 & 362 & 86.5 & 356 & 94.5 & 355 & 93.5 & 69 & 121.5 & 157 & 215.5 & 341 & 142.5 & 54 & 155.0 \\
\hline & 381 & 101.0 & 285 & 99.0 & 96 & 106.5 & 374 & 101.5 & 212 & 119.0 & 106 & 175.0 & 328 & 142.0 & 357 & 145.0 \\
\hline & 43 & 102.0 & 356 & 99.5 & 362 & 107.0 & 356 & 105.5 & 223 & 118.5 & 54 & 172.0 & 96 & 141.5 & 74 & 126.0 \\
\hline
\end{tabular}


Table 3. Contd.

\begin{tabular}{|c|c|c|c|c|c|c|c|c|c|c|c|c|c|c|c|c|}
\hline & 45 & 108.0 & 382 & 99.5 & 212 & 113.0 & 388 & 109.5 & 214 & 114.0 & 352 & 172.0 & 50 & 136.5 & 136 & 124.0 \\
\hline & 212 & 108.0 & 328 & 101.5 & 355 & 113.0 & 68 & 110.5 & 54 & 113.5 & 281 & 164.0 & 212 & 128.5 & 79 & 121.0 \\
\hline & 44 & 108.5 & 371 & 103.5 & 371 & 114.5 & 362 & 112.5 & & 112.5 & 328 & 158.0 & 254 & 127.5 & 78 & 120.5 \\
\hline & 92 & 108.5 & 41 & 105.5 & 388 & 116.0 & 16 & 116.0 & 185 & 110.5 & 336 & 146.0 & 54 & 126.5 & 354 & 120.0 \\
\hline & 49 & 110.0 & 376 & 105.5 & 2 & 116.5 & 314 & 116.5 & 211 & 108.5 & 212 & 144.5 & 205 & 117.5 & 222 & 119.5 \\
\hline & 194 & 110.5 & 291 & 106.0 & 54 & 117.0 & 385 & 118.5 & 292 & 107.0 & 239 & 139.0 & 140 & 116.0 & 96 & 119.0 \\
\hline & 68 & 152.5 & 309 & 156.5 & 83 & 159.0 & 89 & 167.0 & 28 & 7.0 & 14 & 23.5 & 129 & 11.5 & 19 & 11.0 \\
\hline & 24 & 153.0 & 15 & 157.0 & 155 & 159.0 & 124 & 167.0 & 33 & 7.0 & 167 & 27.0 & 180 & 11.5 & 32 & 10.0 \\
\hline & 33 & 153.0 & 133 & 157.0 & 7 & 159.5 & 155 & 167.0 & 18 & 6.5 & 180 & 16.5 & 275 & 11.5 & 4 & 9.5 \\
\hline & 294 & 153.5 & 24 & 161.0 & 58 & 161.0 & 253 & 167.0 & 20 & 6.5 & 338 & 16.0 & 11 & 11.0 & 26 & 9.0 \\
\hline \multirow{6}{*}{ Bottom ten lines } & 32 & 154.5 & 253 & 163.5 & 342 & 161.0 & 255 & 167.0 & 24 & 6.5 & 307 & 25.0 & 344 & 10.5 & 37 & 9.0 \\
\hline & 307 & 154.5 & 82 & 164.0 & 169 & 162.0 & 259 & 167.0 & 5 & 6.0 & 310 & 12.5 & 20 & 9.5 & 1 & 6.0 \\
\hline & 12 & 155.5 & 294 & 164.0 & 82 & 163.0 & 329 & 167.0 & 11 & 6.0 & 13 & 13.0 & 24 & 9.0 & 8 & 6.0 \\
\hline & 298 & 156.0 & 303 & 164.0 & 192 & 163.5 & 104 & 167.5 & 17 & 6.0 & 18 & 6.5 & 38 & 8.5 & 17 & 6.0 \\
\hline & 301 & 156.0 & 196 & 164.5 & 260 & 163.5 & 186 & 167.5 & 12 & 5.0 & 12 & 5.0 & 25 & 4.5 & 18 & 6.0 \\
\hline & 10 & 158.5 & 387 & 164.5 & 271 & 164.5 & 272 & 172.0 & 32 & 4.0 & 177 & 15.5 & 17 & 3.5 & 28 & 4.5 \\
\hline \multirow[t]{2}{*}{ Mean } & & 133.9 & & 133.8 & & 138.4 & & 144.0 & & 51.8 & & 65.1 & & 51.3 & & 49.8 \\
\hline & s.e.d. & I.s.d. & & & & & & & s.e.d. & I.s.d. & & & & & & \\
\hline Genotype & 6.61 & 13.0 & & & & & & & 16.21 & 31.8 & & & & & & \\
\hline Experimental environment & 0.67 & 1.3 & & & & & & & 1.64 & 3.2 & & & & & & \\
\hline Genotype*experimental environment & 13.22 & 25.9 & & & & & & & 32.42 & 63.6 & & & & & & \\
\hline $\mathrm{CV} \%$ & 9.60 & & & & & & & & 59.50 & & & & & & & \\
\hline
\end{tabular}

desirable (Figure 5). Line 39 (Caiapo) although it was early it had low yields a case observed also for line 355 (WAB 450-11-1-1-P41-HB).

\section{The scattering of the 25 best rice genotypes for grain yield against different soil $N$ and $P$ conditions}

When the genotypes were displayed for yield versus soil nitrogen $(N)$ and phosphorous $(P)$ level, majority of the twenty five lines were skewed towards less $\mathrm{N}$ tolerance two quadrants (Figure 6 ). The best genotype was 151 (CT16328-CA-18$\mathrm{M})$ because it was the highest yielding and tolerant, although it was not the most tolerant. The most tolerant lines were 340 (CT16355-CA-9-M) 7 (ARCCU1Fa1-L4P3-HB), 260 (CT16342-CA-4M) and 251 (CT16342-CA-13-M), but these were below the mean yield. The least favourable genotype was 382 (WAB 952-B-47AB.1) as it was least tolerant and had the lowest yield among the group. The majority of the lines scattered towards the left showing more tolerance under soil N-P+ condition (Figure 7). The best genotype was 277 (CT16345-CA-4-M) although line 245 (CT16340CA-9-M) had the highest yield, it was less tolerant than 277. Lines 255 (CT16342-CA-2-M) and 361 (WAB 450-I-B-P-28-HB) were the least adapted in terms of yield but were tolerant. The best tolerant lines had yields just slightly above the mean yield. The best adapted lines were 222 (CT16337-CA-3M) and 29 (ARCCU3Fa6-L3P9) in terms of both yield and tolerance, but they were at the 
Table 4. The mean values of PT, NT, 1000 SDWT and yield traits for the 10 best and worst genotypes under four environments (N-P-, N-P+, N+P- and $\mathrm{N}_{+} \mathrm{P}+$ ).

\begin{tabular}{|c|c|c|c|c|c|c|c|c|c|c|c|c|c|c|c|c|}
\hline \multirow{2}{*}{ Parameter } & \multicolumn{8}{|c|}{ Phosphorous tolerance (scale 1-5) } & \multicolumn{8}{|c|}{ Nitrogen tolerance (scale 1-5) } \\
\hline & Lines & N-P- & Lines & $\mathrm{N} \cdot \mathrm{P}^{+}$ & Lines & $\mathrm{N}^{+} \mathrm{P}-$ & Lines & $\mathrm{N}^{+} \mathrm{P}^{+}$ & Lines & N-P- & Lines & $\mathrm{N}-\mathrm{P}^{+}$ & Lines & $\mathrm{N}^{+} \mathrm{P}-$ & Lines & $\mathrm{N}^{+} \mathrm{P}^{+}$ \\
\hline \multirow{10}{*}{ Top ten lines } & 3 & 1.0 & 2 & 1.0 & 14 & 1.0 & 21 & 1.0 & 12 & 1.0 & 6 & 1 & 3 & 1 & 27 & 1 \\
\hline & 4 & 1.0 & 5 & 1.0 & 91 & 1.0 & 27 & 1.0 & 32 & 1.0 & 20 & 1 & 6 & 1 & 303 & 1 \\
\hline & 6 & 1.0 & 6 & 1.0 & 96 & 1.0 & 40 & 1.0 & 68 & 1.0 & 27 & 1 & 27 & 1 & 21 & 1 \\
\hline & 7 & 1.0 & 8 & 1.0 & 98 & 1.0 & 47 & 1.0 & 170 & 1.0 & 30 & 1 & 167 & 1 & 316 & 1 \\
\hline & 8 & 1.0 & 9 & 1.0 & 99 & 1.0 & 118 & 1.0 & 177 & 1.0 & 167 & 1 & 170 & 1 & 170 & 1.5 \\
\hline & 9 & 1.0 & 14 & 1.0 & 100 & 1.0 & 121 & 1.0 & 180 & 1.0 & 307 & 1 & 247 & 1 & 247 & 1.5 \\
\hline & 15 & 1.0 & 17 & 1.0 & 113 & 1.0 & 187 & 1.0 & 352 & 1.0 & 13 & 1.5 & 250 & 1 & 282 & 1.5 \\
\hline & 16 & 1.0 & 18 & 1.0 & 116 & 1.0 & 195 & 1.0 & 1 & 1.5 & 272 & 1.5 & 256 & 1 & 300 & 1.5 \\
\hline & 22 & 1.0 & 19 & 1.0 & 117 & 1.0 & 245 & 1.0 & 3 & 1.5 & 280 & 1.5 & 282 & 1 & 332 & 1.5 \\
\hline & 29 & 1.0 & 20 & 1.0 & 122 & 1.0 & 315 & 1.0 & 4 & 1.5 & 294 & 1.5 & 294 & 1 & 338 & 1.5 \\
\hline \multirow{10}{*}{ Bottom ten lines } & 247 & 4.0 & 339 & 3.5 & 189 & 3.0 & 10 & 4.5 & 381 & 3.5 & 380 & 4 & 316 & 4 & 13 & 4.5 \\
\hline & 288 & 4.0 & 348 & 3.5 & 196 & 3.0 & 39 & 4.5 & 383 & 3.5 & 384 & 4 & 322 & 4 & 16 & 4.5 \\
\hline & 299 & 4.0 & 352 & 3.5 & 259 & 3.0 & 77 & 4.5 & 388 & 3.5 & 386 & 4 & 327 & 4 & 60 & 4.5 \\
\hline & 345 & 4.0 & 357 & 3.5 & 268 & 3.0 & 79 & 4.5 & 213 & 4.0 & 107 & 4.5 & 333 & 4 & 197 & 4.5 \\
\hline & 362 & 4.0 & 362 & 3.5 & 298 & 3.0 & 216 & 4.5 & 238 & 4.0 & 150 & 4.5 & 335 & 4 & 355 & 4.5 \\
\hline & 374 & 4.0 & 15 & 4.0 & 312 & 3.0 & 268 & 4.5 & 240 & 4.0 & 263 & 4.5 & 340 & 4 & 75 & 4.5 \\
\hline & 270 & 4.5 & 75 & 4.0 & 314 & 3.0 & 270 & 4.5 & 283 & 4.0 & 301 & 4.5 & 344 & 4 & 270 & 4.5 \\
\hline & 300 & 4.5 & 249 & 4.0 & 28 & 3.5 & 332 & 4.5 & 291 & 4.0 & 358 & 4.5 & 343 & 4.5 & 281 & 4.5 \\
\hline & 375 & 4.5 & 263 & 4.0 & 34 & 3.5 & 375 & 4.5 & 342 & 4.0 & 267 & 5 & 240 & 5 & 42 & 5 \\
\hline & 168 & 5.0 & 346 & 4.0 & 352 & 3.5 & 379 & 4.5 & 382 & 4.0 & 39 & 5 & 39 & 4.5 & 39 & 4.5 \\
\hline \multirow[t]{2}{*}{ Mean } & & 1.9 & & 1.8 & & 1.7 & & 2.6 & & 2.7 & & 3.391 & & 3.058 & & 3.199 \\
\hline & s.e.d. & I.s.d. & & & & & & & s.e.d. & I.s.d. & & & & & & \\
\hline Genotype & 0.529 & 1.0 & & & & & & & 0.42 & 0.8 & & & & & & \\
\hline Experimental environment & 0.054 & 0.1 & & & & & & & 0.04 & 0.1 & & & & & & \\
\hline Genotype*experimental environment & 1.058 & 2.1 & & & & & & & 0.83 & 1.6 & & & & & & \\
\hline \multirow[t]{3}{*}{ CV\% } & 52.900 & & & & & & & & 27.00 & & & & & & & \\
\hline & \multicolumn{8}{|c|}{1000 seed weight $(g)$} & \multicolumn{8}{|c|}{ Yield (kgha-1) } \\
\hline & Lines & N-P- & Lines & $\mathbf{N} \cdot \mathbf{P}^{+}$ & Lines & $\mathrm{N}+\mathrm{P}-$ & Lines & $\mathrm{N}^{+} \mathrm{P}^{+}$ & Lines & $N \cdot P \cdot$ & Lines & $\mathrm{N} \cdot \mathrm{P}^{+}$ & Lines & $\mathbf{N}+\mathbf{P}-$ & Lines & $\mathrm{N}^{+} \mathrm{P}^{+}$ \\
\hline \multirow{4}{*}{ Top ten lines } & 163 & 27.9 & 55 & 25.8 & 325 & 28.9 & 140 & 29.2 & 151 & 5916.0 & 245 & 4948.0 & 222 & 4967.0 & 370 & 4970.0 \\
\hline & 238 & 26.8 & 330 & 25.7 & 76 & 28.1 & 370 & 29.0 & 370 & 5911.0 & 277 & 4939.0 & 19 & 4964.0 & 251 & 4954.0 \\
\hline & 171 & 26.4 & 16 & 24.8 & 138 & 27.3 & 23 & 27.8 & 259 & 5904.0 & 360 & 4916.0 & 29 & 4944.0 & 360 & 4940.0 \\
\hline & 165 & 26.2 & 165 & 24.5 & 54 & 27.1 & 29 & 27.7 & 253 & 5884.0 & 364 & 4912.0 & 54 & 4944.0 & 378 & 4937.0 \\
\hline
\end{tabular}


Table 4. Contd.

\begin{tabular}{|c|c|c|c|c|c|c|c|c|c|c|c|c|c|c|c|c|}
\hline & 126 & 25.9 & 38 & 24.3 & 279 & 26.6 & 384 & 27.5 & 163 & 5877.0 & 55 & 4902.0 & 378 & 4943.0 & 387 & 4936.0 \\
\hline & 385 & 25.7 & 153 & 23.6 & 249 & 26.4 & 119 & 27.5 & 354 & 5875.0 & 76 & 4892.0 & 181 & 4936.0 & 212 & 4933.0 \\
\hline & 372 & 25.2 & 186 & 22.9 & 175 & 26.1 & 259 & 27.4 & 74 & 5871.0 & 134 & 4867.0 & 353 & 4934.0 & 222 & 4927.0 \\
\hline & 9 & 25.0 & 289 & 22.9 & 380 & 25.9 & 163 & 27.4 & 182 & 5869.0 & 293 & 4852.0 & 273 & 4930.0 & 186 & 4925.0 \\
\hline & 383 & 24.3 & 385 & 22.8 & 351 & 25.9 & 236 & 27.3 & 77 & 5864.0 & 63 & 4848.0 & 104 & 4922.0 & 353 & 4925.0 \\
\hline & 307 & 24.3 & 191 & 22.4 & 388 & 25.8 & 151 & 27.2 & 54 & 5862.0 & 127 & 4847.0 & 117 & 4918.0 & 141 & 4921.0 \\
\hline & 344 & 6.3 & 363 & 5.5 & 39 & 7.1 & 347 & 12.9 & 125 & 990.0 & 363 & 1480.0 & 129 & 1757.0 & 179 & 1560.0 \\
\hline & 243 & 6.0 & 314 & 5.4 & 134 & 6.9 & 101 & 12.8 & 152 & 949.0 & 257 & 1457.0 & 313 & 1750.0 & 324 & 1500.0 \\
\hline & 390 & 5.9 & 105 & 5.4 & 209 & 6.8 & 125 & 12.6 & 363 & 948.0 & 216 & 1410.0 & 85 & 1725.0 & 124 & 1450.0 \\
\hline \multirow[t]{5}{*}{ Bottom ten lines } & 346 & 5.7 & 274 & 5.2 & 83 & 6.6 & 43 & 12.5 & 263 & 914.0 & 264 & 1407.0 & 267 & 1725.0 & 203 & 1413.0 \\
\hline & 61 & 5.6 & 124 & 4.8 & 269 & 6.5 & 176 & 12.4 & 168 & 912.0 & 291 & 1350.0 & 270 & 1700.0 & 10 & 1400.0 \\
\hline & 168 & 5.3 & 344 & 4.6 & 198 & 6.5 & 246 & 12.2 & 225 & 848.0 & 270 & 1300.0 & 216 & 1635.0 & 320 & 1234.0 \\
\hline & 92 & 5.3 & 229 & 4.2 & 45 & 6.1 & 320 & 11.8 & 344 & 715.0 & 310 & 1200.0 & 363 & 1471.0 & 75 & 1114.0 \\
\hline & 177 & 4.9 & 292 & 4.1 & 141 & 5.5 & 187 & 11.5 & 345 & 549.0 & 249 & 1020.0 & 218 & 1150.0 & 263 & 1065.0 \\
\hline \multirow[t]{2}{*}{ Mean } & & 14.7 & & 14.2 & & 17.1 & & 19.7 & & 3828.0 & & 3676.0 & & 3491.0 & & 3559.0 \\
\hline & s.e.d. & I.s.d. & & & & & & & s.e.d. & I.s.d. & & & & & & \\
\hline Genotype & 3.17 & 6.2 & & & & & & & 541.40 & 1062.0 & & & & & & \\
\hline Experimental environment & 0.32 & 0.6 & & & & & & & 54.80 & 107.6 & & & & & & \\
\hline Genotype ${ }^{*}$ experimental environment & 6.34 & 12.4 & & & & & & & 1082.80 & 2124.0 & & & & & & \\
\hline $\mathrm{CV} \%$ & 38.70 & & & & & & & & 29.80 & & & & & & & \\
\hline
\end{tabular}

demarcation line for tolerance (Figure 8). The least adapted lines were 102 (CT16319-CA-13-M) and 81 (CT16315(1)-CA-1-M) because they were low yielding although tolerant to soil $\mathrm{N}$ and $\mathrm{P}$ condition. The majority of the lines were at the medium tolerance line but many were above the mean yield. The best line 370 (WAB 880-1-38-2028-P1 HB) in terms of yield was less adapted to soil $\mathrm{N}$ and $\mathrm{P}$ condition, while the best tolerant lines 94 (CT16316-CA-8-M), 342 (CT16356(1)-CA-2-M) and 334 (CT16355-CA-15-M) had yields below the average (Figure 9). The majority of the lines congregated towards high yielding but less tolerant and low yielding but more tolerant quadrants.

\section{DISCUSSION}

The germplasm under study showed genetic variability for all the traits studied partly because these were accessions from diverse origins. Majority of the germplasm was also well adapted to the local conditions and this might have been con- tributed by the use of Oryza glaberrima as a parent in the development of some of these materials. This species is native to western Africa and is known to be tolerant to a wide range of abiotic and biotic factors (Sarla and Swamy, 2005; WARDA, 2006). The $\mathrm{H}^{2}$, GA and GAM had positive values indicating that breeding for the traits is feasible (Karim et al., 2007).

It means then that selection of the parents with the desirable traits of interest (as guided by genotypic variance) to farmers and use of these in 
Table 5. The mean values of plant height and top biomass traits for the 10 best and worst genotypes under four environments $\left(\mathrm{N}^{-} \mathrm{P}^{-}, \mathrm{N}^{-} \mathrm{P}^{+}, \mathrm{N}^{+} \mathrm{P}^{-}\right.$and $\left.\mathrm{N}^{+} \mathrm{P}^{+}\right)$.

\begin{tabular}{|c|c|c|c|c|c|c|c|c|c|c|c|c|c|c|c|c|}
\hline \multirow{2}{*}{ Parameter } & \multicolumn{8}{|c|}{ Plant height $(\mathrm{cm})$} & \multicolumn{8}{|c|}{ Top biomass (g) } \\
\hline & Lines & N-P- & Lines & $N \cdot P^{+}$ & Lines & $\mathrm{N}+\mathrm{P}-$ & Lines & $\mathrm{N}^{+} \mathrm{P}^{+}$ & Lines & $N \cdot P-$ & Lines & $\mathrm{N} \cdot \mathrm{P}^{+}$ & Lines & $\mathrm{N}+\mathrm{P}-$ & Lines & $\mathrm{N}^{+} \mathrm{P}^{+}$ \\
\hline \multirow{10}{*}{ Top ten lines } & 77 & 107.5 & 272 & 110.9 & 175 & 114.7 & 221 & 115.2 & 272 & 3888.5 & 175 & 3088.5 & 254 & 2690.0 & 175 & 2495.0 \\
\hline & 34 & 103.4 & 175 & 106.8 & 254 & 112.1 & 259 & 112.9 & 259 & 2406.5 & 272 & 2882.0 & 341 & 2616.0 & 159 & 2378.0 \\
\hline & 74 & 101.3 & 289 & 105.9 & 337 & 110 & 176 & 112.8 & 254 & 2271.5 & 54 & 2810.5 & 175 & 2582.0 & 149 & 2154.5 \\
\hline & 171 & 99.4 & 269 & 105.5 & 119 & 109.1 & 116 & 110.2 & 131 & 2249.0 & 159 & 2121.0 & 159 & 2490.5 & 221 & 1867.0 \\
\hline & 319 & 97.8 & 94 & 103.5 & 272 & 108.7 & 78 & 109.4 & 341 & 2170.0 & 176 & 2093.0 & 96 & 2349.5 & 167 & 1842.8 \\
\hline & 88 & 96.7 & 254 & 103.0 & 76 & 108.6 & 226 & 108.2 & 54 & 2075.0 & 212 & 2024.5 & 94 & 2346.4 & 142 & 1842.0 \\
\hline & 134 & 96.7 & 335 & 102.6 & 221 & 106.9 & 285 & 107.9 & 74 & 2031.0 & 277 & 1999.5 & 372 & 2106.5 & 255 & 1823.5 \\
\hline & 89 & 96.2 & 22 & 102.5 & 342 & 105.4 & 80 & 107.7 & 242 & 2031.0 & 341 & 1965.0 & 50 & 2049.5 & 170 & 1815.5 \\
\hline & 272 & 95.6 & 91 & 102.5 & 183 & 103.7 & 142 & 107.1 & 212 & 1810.5 & 148 & 1916.0 & 54 & 2004.5 & 254 & 1617.0 \\
\hline & 155 & 95.2 & 63 & 101.6 & 336 & 102.6 & 62 & 107.0 & 305 & 1750.5 & 254 & 1901.5 & 63 & 1973.0 & 166 & 1598.0 \\
\hline \multirow{10}{*}{ Bottom ten lines } & 362 & 62.4 & 185 & 86.0 & 321 & 62 & 173 & 58.2 & 31 & 50.5 & 3 & 124.5 & 297 & 146.5 & 32 & 94.5 \\
\hline & 33 & 62.0 & 297 & 71.5 & 216 & 61.6 & 232 & 58.0 & 310 & 50.5 & 332 & 124.0 & 130 & 144.5 & 31 & 88.5 \\
\hline & 36 & 61.8 & 249 & 60.9 & 320 & 57.5 & 228 & 57.8 & 330 & 45.0 & 344 & 112.5 & 352 & 142.5 & 234 & 85.5 \\
\hline & 190 & 61.6 & 343 & 66.6 & 345 & 57 & 195 & 57.5 & 247 & 38.0 & 180 & 112.0 & 8 & 125.5 & 97 & 72.5 \\
\hline & 275 & 61.5 & 225 & 93.3 & 340 & 56.8 & 216 & 57.5 & 250 & 37.0 & 34 & 110.0 & 36 & 124.0 & 19 & 59.5 \\
\hline & 350 & 61.2 & 339 & 65.7 & 386 & 56.2 & 287 & 56.5 & 17 & 33.0 & 14 & 103.5 & 269 & 123.5 & 28 & 53.0 \\
\hline & 28 & 61.1 & 224 & 78.5 & 75 & 55.32 & 344 & 56.5 & 32 & 31.0 & 12 & 87.5 & 20 & 107.0 & 10 & 48.0 \\
\hline & 249 & 60.9 & 301 & 72.3 & 343 & 52 & 306 & 55.8 & 36 & 28.0 & 338 & 84.5 & 4 & 105.5 & 18 & 48.0 \\
\hline & 73 & 60.3 & 263 & 68.9 & 39 & 46.5 & 39 & 55.2 & 16 & 23.5 & 39 & 51.0 & 32 & 101.0 & 17 & 35.5 \\
\hline & 173 & 58.2 & 273 & 79.0 & 344 & 46 & 320 & 55.2 & 345 & 12.5 & 13 & 45.0 & 25 & 25.0 & 8 & 23.0 \\
\hline \multirow[t]{2}{*}{ Mean } & & 78.4 & & 82.7 & & 82.98 & & 81.9 & & 674.9 & & 719.5 & & 691.8 & & 610.4 \\
\hline & s.e.d. & I.s.d. & & & & & & & s.e.d. & I.s.d. & & & & & & \\
\hline Genotype & 5.78 & 11.3 & & & & & & & 198.15 & 388.7 & & & & & & \\
\hline Experimental environment & 0.59 & 1.1 & & & & & & & 20.07 & 39.4 & & & & & & \\
\hline Genotype ${ }^{*}$ experimental environment & 11.56 & 22.7 & & & & & & & 396.31 & 777.4 & & & & & & \\
\hline CV\% & 14.20 & & & & & & & & 58.80 & & & & & & & \\
\hline
\end{tabular}

a breeding programme can enhance the such as drought and late stage nutrient deficiency, especially the one resulting from water stress. In rice, genotypes that have anthesis within a narrow range should be selected to reduce prolonged maturity and thus escape terminal drought. In maize, the anthesis-silking interval has been exploited to develop drought and nitrogen use efficient varieties (Bolanos and Edmeades, 1996).

Rice, although it is a self pollinated crop, the wide gap between heading and anthesis is variable and this is not a desirable trait. This heading-anthesis gap can lead to differential maturity with consequent problems such as grain shattering for the earliest panicles, grain discolouration and loss of quality due to over drying in the field and in case of late drought, materials with later anthesis may not have good grains set. Generally this gap should be between 1 to 5 days for uniform crop maturity thus good grain quality, because crop harvesting can be done at the right physiological 
Kimani et al. 361

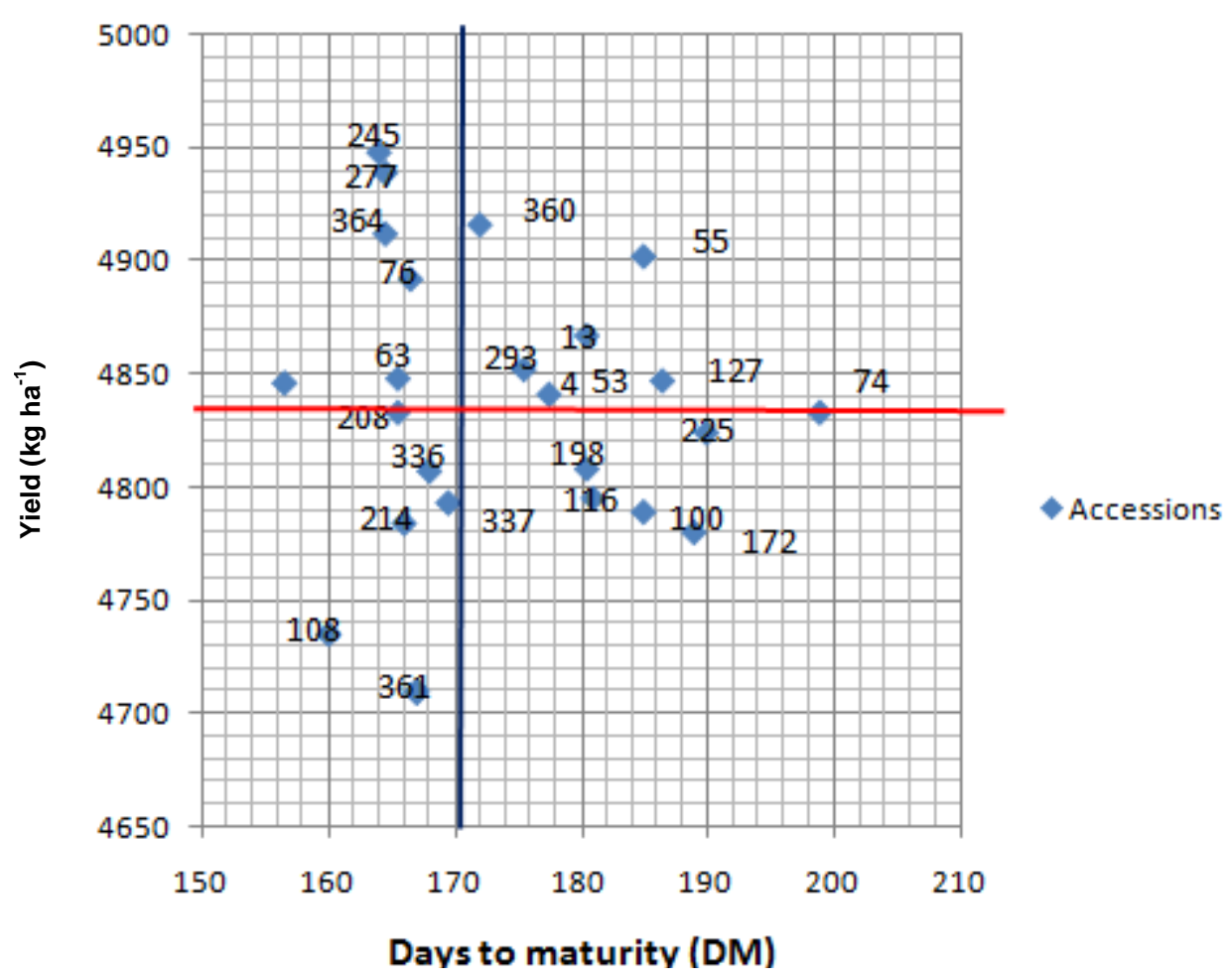

Figure 3. Yield against days to maturity of the best rice genotypes under Soil $\mathrm{N}^{-} \mathrm{P}^{+}$conditions.

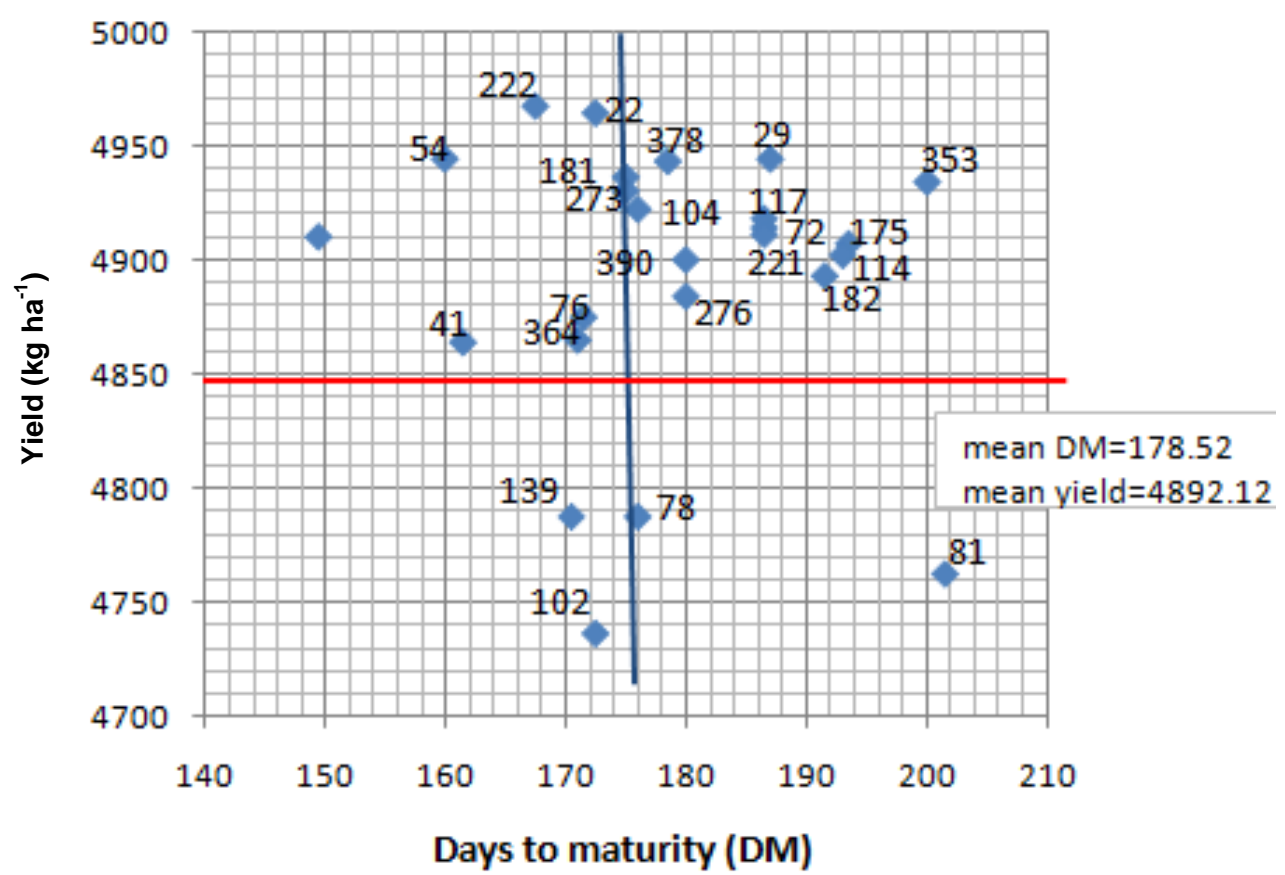

Figure 4. Yield against days to maturity of the best rice genotypes under soil $\mathrm{N}^{+} \mathrm{P}^{-}$conditions.

stage.

The maturity period varied greatly with a range of 116 days for 39 (Caiapo) and 140 days for 378 (WAB 905-B$4 \mathrm{~A}$ 1.1) and this was under $\mathrm{N}^{-} \mathrm{P}^{+}$and $\mathrm{N}^{-} \mathrm{P}^{-}$experimental environments, respectively for earliest selected genotypes. The range of 24 days can be exploited by breeding varieties that mature early and thus escape terminal drought (Atlin et al., 2006b; Bing et al., 2005; Blum, 2000; 


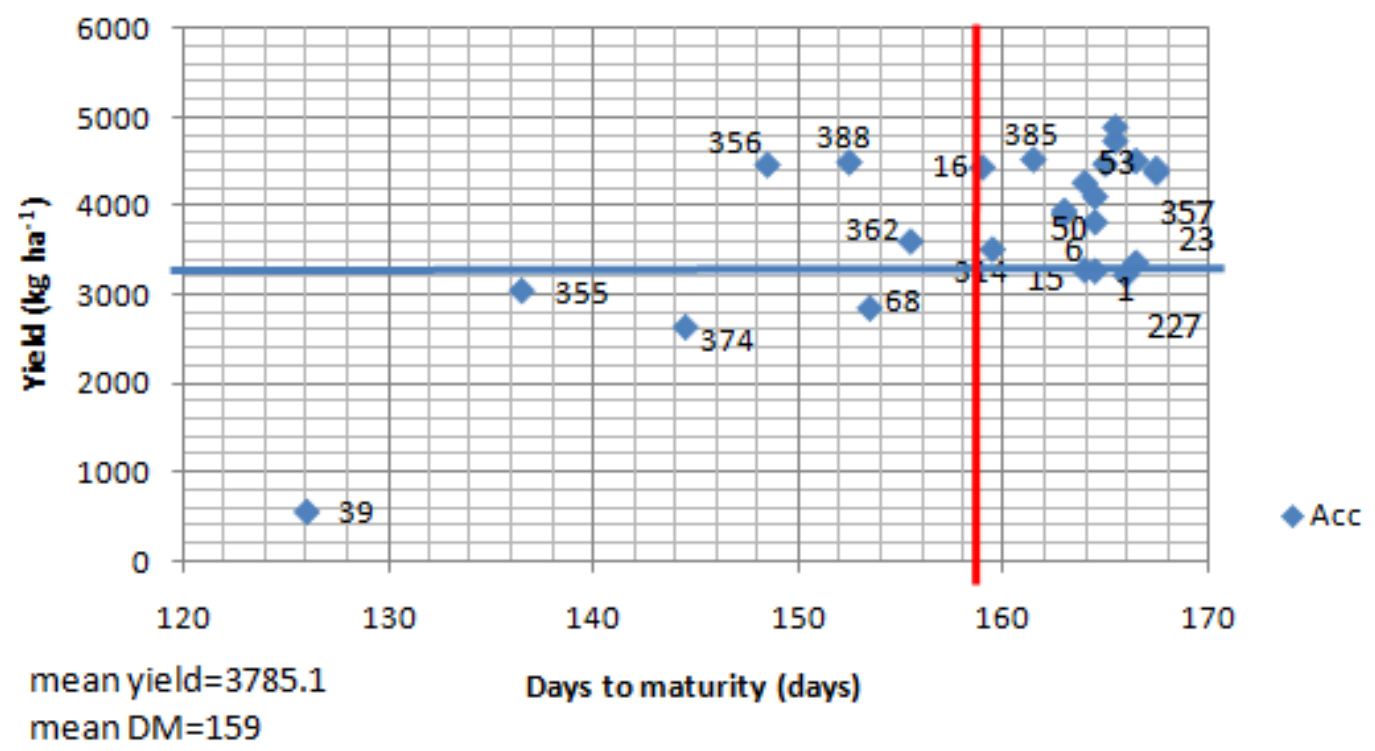

Figure 5. Analysis of yield and days to maturity of the best rice genotypes under soil $\mathrm{N}^{+} \mathrm{P}^{+}$conditions.



Figure 6. Head to head plot of the best 25 rice lines for yield versus soil $\mathrm{N}^{-}$and $\mathrm{P}^{-}$condition.

Boonjung and Fukai, 1996) Since $\mathrm{H}^{2}$ was low at $23.9 \%$ for days to maturity, modified bulk method without selection until the materials are fairly homozygousat about $F_{5}$ to $F_{6}$ generation, should be emphasized as simple mass selection cannot be efficient in this case. Heritability is used to establish the expected improvement or progress after selection of genotypes from a given population (Nyquist, 1991).

From the display of scatter plot of yield versus days to maturity under soil $\mathrm{N}^{-} \mathrm{P}^{-}$condition (Figure 2 ) among the best high yielding genotypes, a number of them were in the desired quadrant of high yielding and early maturing (lines 378, 212, 381 and 368). However, majority of the genotypes congregated in the high yielding but late genotypes confirming that late genotypes tend to be high yielding. The performance under soil $\mathrm{N}^{-} \mathrm{P}^{+}$condition had different genotypes in the early and high yielding quadrant from those obtained under soil $\mathrm{N}^{-} \mathrm{P}^{-}$condition (Figure 3). Probably the reason for this behaviour is that different gene system or quantitative trait loci (QTL) are 


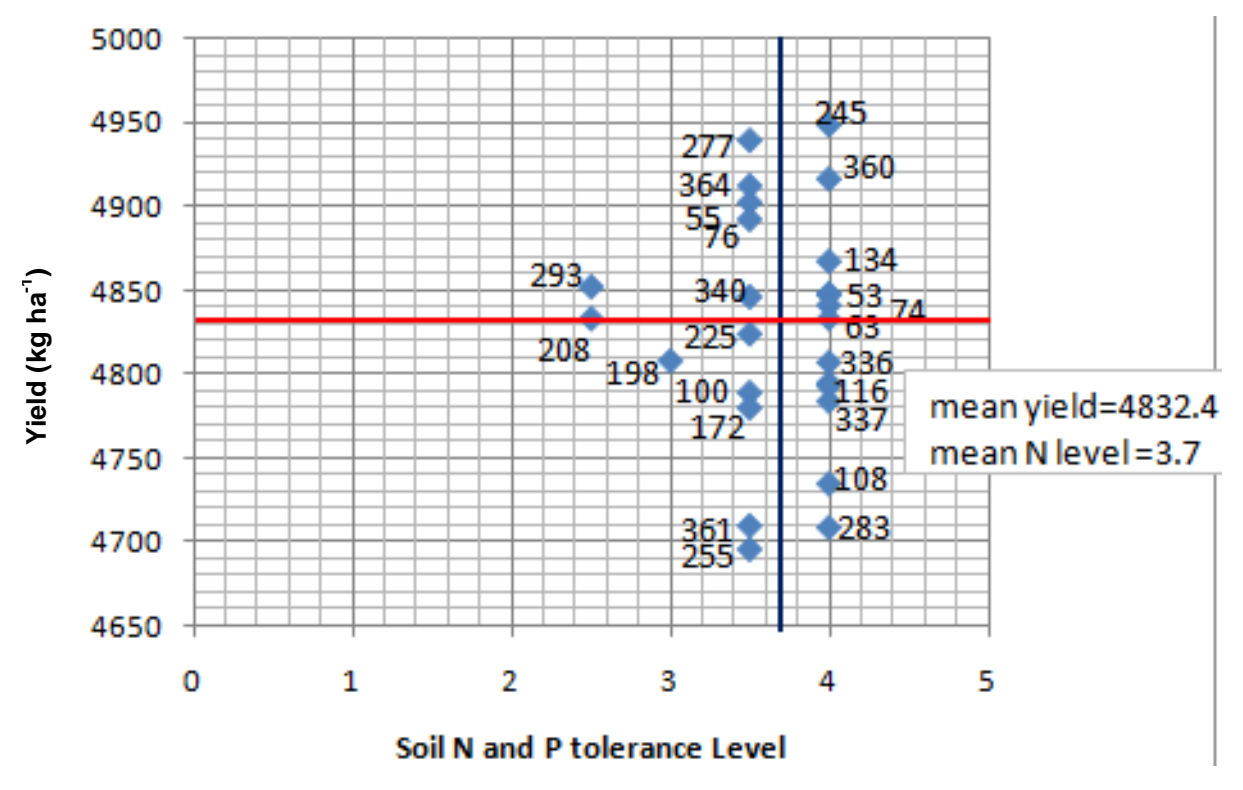

Figure 7. Head to head plot of the best 25 rice lines for yield versus soil $\mathrm{N}^{-}$and $\mathrm{P}^{+}$condition.



Figure 8. Head to head plot of the best 25 rice lines for yield versus soil $\mathrm{N}^{+}$and $\mathrm{P}^{-}$condition.

operating for each of the two soils $\mathrm{N}$ and $\mathrm{P}$ conditions, thus the need to breed specific genotypes for each soil $\mathrm{N}$ and $\mathrm{P}$ condition. The performance under soil $\mathrm{N}^{+} \mathrm{P}$ - had two genotype $(76,364)$ occurring in the desired quadrant just as under soil $\mathrm{N}^{-} \mathrm{P}^{+}$condition, but was under soil N-P+ condition. The two lines may be having the same adaptation mechanism because the rest of the 23 genotypes were in different quadrants. The quadrant for early and high yielding lines under soil $\mathrm{N}^{+} \mathrm{P}^{+}$condition (Figure 5) had different genotypes from all the other three soil condition cases. This indicates that different adaptation mechanisms are in operation for each of the four soil $\mathrm{N}$ and $\mathrm{P}$ conditions. The worst genotype was 39 as it was poorly adapted as indicated by its low yield although it was quite early. The foregoing clearly indicates the need to breed different genotypes for different soil $\mathrm{N}$ and $\mathrm{P}$ conditions.

\section{Plant height and above ground biomass production}

Farmers indicated their preference for tall plants. The top genotypes had a range of 108 to $115 \mathrm{~cm}^{-1}$ under $\mathrm{NP}^{-}$and 


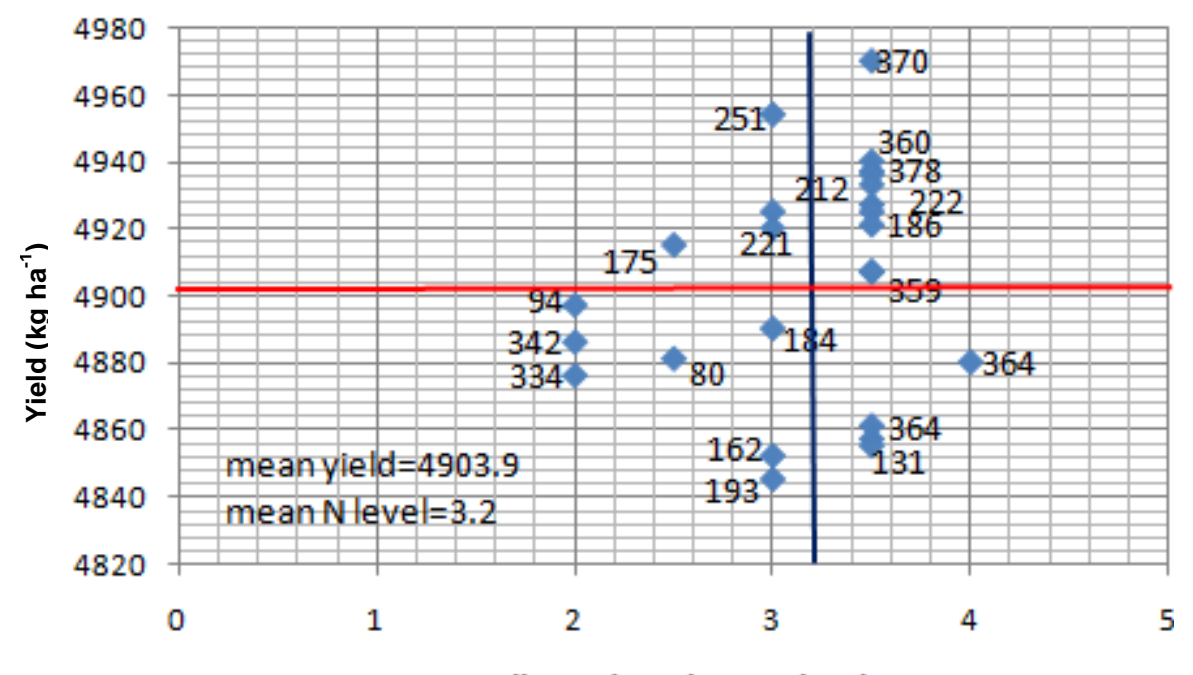

Soil $\mathbf{N}$ and $\mathbf{P}$ tolerance level

Figure 9. Head to head plot of the best 25 rice lines for yield versus soil $\mathrm{N}_{+}$and $\mathrm{P}+$ condition.

$\mathrm{N}^{+} \mathrm{P}^{-}$experimental conditions. This is in contrast to the shortest rice plants, which had a range of 46 to $79 \mathrm{~cm}$ under $\mathrm{N}^{+} \mathrm{P}^{-}$and $\mathrm{N}^{-} \mathrm{P}^{+}$conditions (Table 5). This diversity can be harnessed through breeding to produce the preferred height by farmers. Farmers, in a participatory plant breeding trial, had pointed out during focus group discussion and key informants, that tall plants were easy to; harvest, a finding also observed in West Africa (Efisue et al., 2008); collect their culms and use them for livestock feed, making farm yard manure and thatching sheds. They also argued that short rice plants are normally prone to damage from flooding, splash water, rodents, ground birds and termites. They also indicated that short varieties are tiresome due to excessive bending during harvesting, cutting and threshing, views that were also found in West Africa (Efisue et al., 2008). The $\mathrm{H}^{2}$ value for this trait was $27.3 \%$ and since it is selected visually, this trait can be improved easily provided the various sources of the height and yield genes are present in the parents used for crossing (Simmonds and Smartt, 1999).

The values for TB for the top genotypes ranged from 2495 to $3889 \mathrm{~g}$ under $\mathrm{N}^{+} \mathrm{P}^{+}$and $\mathrm{NP}^{-}$conditions. The difference was $1394 \mathrm{~g}$ thus exhibiting wide variation among the genotypes for this trait. The lowest TB weight values observed for experimental environments had a range of $12.5 \mathrm{~g}$ under $\mathrm{N}^{-} \mathrm{P}^{-}$to $45 \mathrm{~g}$ under $\mathrm{NP}^{-}$condition (Table 5). Comparison of these two groups reveals that the genetic diversity for culm biomass was high. The general trend appeared to be that the CT series materials from CIAT Columbia tended to have more biomass and occupied much of the top ten (Table 5), while Africa Rice Centre germplasm (ARC and WAB series) occupied the bottom ten band. It therefore implies that the CT series materials were more adapted to varying conditions of $P$ and N. Selection for this trait may not be difficult, since visual observation can partly be used to carry out selection. The degree of genetic determination $\left(\mathrm{H}^{2}\right)$ (Falconer and Mackay, 1996) was highest (36.5\%) for TB among all the other characters, further backing up the fact that, the trait is fairly heritable and its breeding may not pose much challenge. The genotypes that tended to have high biomass also had generally high yields, indicating high possibility of breeding varieties that combine the two traits.

\section{The tolerance of genotypes under different soil $P$ and $\mathrm{N}$ condition}

The phosphorous tolerance (PT) values ranged from an overall mean of $1.703\left(\mathrm{~N}^{+} \mathrm{P}^{-}\right)$and $2.62\left(\mathrm{~N}^{+} \mathrm{P}^{+}\right)$, while that of nitrogen tolerance (NT) was $2.7\left(\mathrm{NP}^{-}\right)$and $3.391\left(\mathrm{~N}^{-}\right.$ $\mathrm{P}^{+}$). Generally the top ten genotypes had a value of 1.0 for PT, but those of NT ranged from 1.0 to 1.5. This diversity in tolerance range can be utilized to develop genotypes with high nutrient use efficiency under the prevailing production environments and take advantage of any applied inputs. This could entail breeding for specific adaptation instead of broad adaptation (Ceccarelli, 1994; Christiansen and Lewis, 1982; Dudal, 1976; Fukai et al., 1999; Kimani and Derera, 2009; Kimani et al., 2007; Pinheiro et al., 2006; Yoji et al., 1992). The majority of the modern cultivars have been bred for high input environments, but the cost of the inputs is prohibitive to the majority of the farmers. Further, the farming systems that encourage soil replenishment have been abandoned or proved inapplicable mainly because of the population pressure, infrastructure development and climate change (Roder et al., 1995; Saito et al., 2006); thus aggravating the problem of low soil $\mathrm{N}$ and $\mathrm{P}$ and therefore, the need 
for input efficient genotypes. These systems were slash and burn, shifting cultivation and crop rotation. It is no longer possible to practice these elementary and subsistence systems and since farming is nowadays highly commercial (Kirk et al., 1998; Smaling et al., 1997), the fields are rarely left fallow or rotated with other crops as an effort to maintain soil health (Donovan et al., 1999; Fukai et al., 1999; Kirk et al., 1998; Wonprasaid et al., 1996). The fallow periods may be long and thus unrealistic, the uplands are poorly managed thus eroded resulting in poor soil fertility (Kirk et al., 1998). It is now imperative that the crop improvement programmes should undergo a paradigm shift from concentrating on high input dependent varieties to screening for adaptation and selecting the efficient varieties for development or improving the cultivars in order to exploit the vast unexploited problem soil areas. Upland rice has immense potential in Kenya as much of the land is unexploited this therefore, calls for a shift from high input dependent varieties to efficient varieties targeted to the prevailing specific environments used by farmers for production.

The scatter plots of yield versus soil $\mathrm{N}$ and $\mathrm{P}$ tolerance levels had varied results (Figures 6 to 9 ). Under soil $\mathrm{NP}^{-}$, line 74 was the most desirable because it was tolerant to low soil $\mathrm{N}$ and $\mathrm{P}$ and had the highest yield under high yielding and tolerant quadrant. This means it is easy to select genotypes according to their adaptability. Under N$\mathrm{P}+$ soil condition, line 277 was the highest yielding although not the most adapted. The line 104 was the best but it was not the highest yielding under soil $\mathrm{N}+\mathrm{P}$ - condition. Under the optimum soil condition the best genotype was 251 as it was the most adapted (Figure 9). It is clear that different lines are specifically adapted to certain soil $\mathrm{N}$ and $\mathrm{P}$ conditions, and that breeding for a super variety with broad adaptation is not quite easy. It seems therefore, that development of varieties should aim for specific adaptation (Ceccarelli, 1994; Fukai et al., 1999).

\section{Yield under varying soil $\mathbf{N}$ and $\mathrm{P}$ conditions}

The number of panicles per plant is an important yield parameter as grain yield is a function of panicles area ${ }^{-1}$ *spikelets panicle ${ }^{-1}{ }^{*}$ fertility of spikelets *weight of grains. Farmers are quite aware of the panicle characteristic and in a participatory plant breeding (PPB) trial; they indicated preference for long well filled clean or shiny panicles withmoderate grain shattering. The best genotypes had number of panicle range of $133\left(\mathrm{~N}^{-} \mathrm{P}\right)$ to $263\left(\mathrm{~N}^{-} \mathrm{P}^{+}\right)$, while the worst had $4\left(\mathrm{~N}^{+} \mathrm{P}\right)$ to $16\left(\mathrm{~N}^{-} \mathrm{P}^{+}\right)$panicles under experimental environments in parenthesis. This diversity of number of panicle can be exploited visually in a breeding programme. The $\mathrm{H}^{2}$ for this trait was $29.1 \%$ being second from that of top biomass, thus indicating fairly good degree of genetic determination (Falconer, 1989).

The materials that had superior yields under low soil fertility conditions can be used for improvement of the local cultivar. The overall mean yield was $3639 \mathrm{~kg} \mathrm{ha}^{-1}$.
However, some materials gave low yield as they were poorly adapted to some of the experimental environments, but the majority of the materials having been bred for drought tolerance and problem soils had high yield, though their performance varied depending on the experimental environments (Table 4). The top yielding genotypes and their experimental environments were 151 (CT16328-CA-18-M) (NP') at $5916 \mathrm{~kg} \mathrm{ha}^{-1}, 245$ (CT16340-CA-9-M) (N- $\left.{ }^{+}\right) 4948 \mathrm{~kg} \mathrm{ha}^{-1}, 222$ (CT16337CA-3-M) (N+P) $4967 \mathrm{~kg} \mathrm{ha}^{-1}, 370$ (WAB880-1-38-20-28$\mathrm{P} 1 \mathrm{HB})\left(\mathrm{N}^{+} \mathrm{P}^{+}\right) 4970 \mathrm{~kg} \mathrm{ha}^{-1}$. The materials from CIAT Columbia (CT series) dominated four top slots across the soil $\mathrm{N}$ and $\mathrm{P}$ conditions, while Africa Rice Centre materials (WAB) were represented by only one under high fertility condition. The best overall high yielding genotype was under low soil fertility conditions ( $\left.\mathrm{N}^{-} \mathrm{P}^{-}\right)$, indicating the fact that breeding rice for problem soil adaptation is a reality as observed also by Gregorio (2002) and Saito et al. (2006).

In contrast, the lowest yielders were 314 (CT16350-CA7-M) (NP) $509 \mathrm{~kg} \mathrm{ha}^{-1}, 301$ (CT16350-CA-2-M) (NP') $850 \mathrm{~kg} \mathrm{ha}^{-1}, 269$ (CT16344-CA-8-M) (N $\left.\mathrm{N}^{+}\right) 800 \mathrm{~kg} \mathrm{ha}^{-1}$, and 39 (Caiapo) $\left(\mathrm{N}^{+} \mathrm{P}^{+}\right) 567 \mathrm{~kg} \mathrm{ha}^{-1}$. Caiapo seems to be poorly adapted to low soil fertility, unlike the other parent O. glaberrima (line 353) that appeared twice in the top ten yielders under $\mathrm{N}^{-} \mathrm{P}^{+}$and $\mathrm{N}^{+} \mathrm{P}^{+}$optimum experimental environment and had yield above $4925 \mathrm{~kg} \mathrm{ha}^{-1}$. Problem soils are widespread throughout the world and breeding rice varieties that are capable of extracting the most fixed nutrients like phosphorous is very important, cost effective and environmentally friendly(Wissuwa and Ae, 2001). The fact that the progenies of these two materials were far above their parents in yield is a clear manifesttation that breeding for higher yields may be met with high success. This can be fairly easy if heritability for yield under low soil $\mathrm{P}$ and $\mathrm{N}$ is high as mass selection can be applied (Borojevi'c, 1990). However, if heritabilities are low, other methods of handling segregating populations that include pedigree, bulk, backcross, and modified bulk method can be used for progress in breeding work (Fasoula et al., 1993; Fawole et al., 1982; Holland et al., 2003; Li et al., 1997; Nyquist, 1991; Verma and Srivastava, 2004).

The 1000 grain weight (unhulled) is another important trait that indicates seed size and yield, where weight is used to sell the produce. The best top genotype had a weight range of $25.79 \mathrm{~g}\left(\mathrm{~N}^{-} \mathrm{P}^{+}\right)$to $29.2 \mathrm{~g}\left(\mathrm{~N}^{+} \mathrm{P}^{+}\right)$, while the lowest performers had a range of $3.83 \mathrm{~g}\left(\mathrm{~N}^{-} \mathrm{P}^{-}\right)$to $10.2 \mathrm{~g}$ $\left(\mathrm{N}^{+} \mathrm{P}^{+}\right)$under the conditions in parenthesis (Table 4). The $\mathrm{H}^{2}$ was low at $8.7 \%$ indicating that bulk breeding method where lines are advanced without selection until they become more homogeneous, may be the procedure to use (Allard, 1960; Chahal and Gosal, 2002; Hallauer and Miranda FO, 1989; Holland et al., 2003; Li et al., 1997; Nyquist, 1991; Rabiei et al., 2004; Smith and Kinman, 1965; Verma and Srivastava, 2004; Wu, 2003). The grain types preferred by Kenyan farmers are the slender long 
white types characteristic of basmati rice.

Aroma is another key attribute as aromatic grains fetch premium prices in the market. However, these aromatic types have low yields and the trait seems to be strongly linked to low yield (Karim et al., 2007; Singh, 2005). The performance of the genotypes was observed to generally have high yields for those lines with poorer grain quality. Lines such as Duorado and NERICA1 that have high grain quality tended to have low yields.

Generally, the notion that development of plants with high extracting ability of nutrients such as $\mathrm{P}$ can be detrimental, especially with no external $P$ supply, because they may deplete soil reserves is farfetched. A part from these plants benefiting from applied nutrients, the soil reservoirs for an element like $P$ can be available for centuries, assuming that the plants are able to extract it. Kirk et al. (1998) have argued on the complex intricacies involved in nutrients dynamics and concluded that development of efficient varieties is the best option available, not only on environmental concerns but also economically.

\section{CONCLUSION AND IMPLICATION}

The accessions were found to be well adapted to the local conditions as indicated by their characterization data of traits like days to maturity, plant height and yield. The variability found in the studied traits like biomass and the high values of $\mathrm{H}^{2}$ obtained is an indication that their heritability was contributed partly by the heritable additive genetic effects. The combined use of $\mathrm{H}^{2}$ estimates, CVP, GA and GAM can be utilized to improve phosphorous, nitrogen tolerance and other yield related components from the population by selecting promising genotypes under the prevailing farmers conditions. The high CVP values or phenotypic variability for traits like TB, NP, PT, yield and 1000 seed weight implies that visual appraisal can be utilized. This can be so in selections from the segregating progenies from crosses made for their improvement. The high GAM values for TB, NP and yield is an indicator of their heritability in the progenies from the parents. Very few genotypes performed well across the soil $\mathrm{N}$ and $\mathrm{P}$ experimental environments. Thus indicating that different genotypes are adapted differently to the environments and that different gene or quantitative trait loci may be involved singly or in groups. This is a clear case of narrow adaptation. One of the genotype, Caiapo, which was one of the parents in the CIAT materials ranked number one for days to heading, anthesis and maturity in terms of earliness. This is an indication and a confirmation that it is possessing genes for earliness and it is therefore, a good choice for parent, where earliness is the breeding objective. The $\mathrm{N}^{-} \mathrm{P}^{-}$environment was found to discriminate well the genes for yield better than $\mathrm{N}^{+} \mathrm{P}^{+}$condition. These materials therefore, can be used to develop varieties adapted to low soil fertility and with the end user desired traits. The two way biplots have shown that genotypes are adapted differently in different soil $\mathrm{N}$ and $\mathrm{P}$ environments.

\section{ACKNOWLEDGEMENTS}

Authors wish to pass our appreciation to the Director of ACCl for providing the study environment. We acknowledge Professor Aggrey B. Nyende of JomoKenyatta University of Agriculture and Technology for his role as ICCS. Funding of this research by AGRA and IFS is highly appreciated. WARDA, CIAT-Colombia, Mali and IRRI are highly acknowledged for provision of breeding materials.

\section{REFERENCES}

Allard RW (1960). Principles of Plant Breeding John Wiley \& Sons, New York, p.264.

Atlin GN, Cooper M, Bjørnstad A (2006a). A comparison of formal and participatory breeding approaches using selection theory. Euphytica, 122(3):463-475.

Atlin GN, Lafitte HR, Tao D, Laza M, Amante M, Courtois B (2006b). Developing rice cultivars for high-fertility upland systems in the Asian tropics. Field Crops Res. 97:43-52.

Banziger M, Setimela PS, Hodson D, Vivek B (2006). Breeding for Improved Abiotic StressTolerance in Maize Adapted to Southern Africa. Agric. Water Manage., 80:212-224.

Bing Y, Lizhong X, Weiya X, Xing Y, Xu C (2005). Genetic analysis for drought resistance of rice at reproductive stage in field with different types of soil. Theor. Appl. Genet., 111:1127-1136.

Blum A (2000). Drought Tolerance - is it a Complex Trait?, Proceedings of an International Workshop on Field Screening for Drought Tolerance in Rice, 11-14 Dec 200, ICRISAT, Patancheru, India. Patancheru 502 324, Andhra Pradesh, India, and the Rockefeller Foundation, New York 10018-2702, USA, pp.17-22.

Bolanos J, Edmeades GO (1996). The importance of the anthesissilking interval in breeding for drought tolerance in tropical maize. Field Crops Res. 48:65-80.

Boonjung H, Fukai S (1996). Effects of soil water deficit at different growth stages on rice growth and yield under upland conditions. 1. Growth during drought. Field Crops Res., 48:37-45.

Borojevi'c S (1990). Principles and Methods of Plant Breeding Amsterdam New York, Elsevier, p.368.

Ceccarelli S (1994). Specific adaptation and breeding for marginal conditions. Euphytica, 77:205-219.

Chahal GS, Gosal SS (2002). Principle and procedures of plant breeding: Biotechnological and conventional approaches. Pangbourne England, Alpha Sci. Intl. Ltd., p.604.

Christiansen MN, Lewis CF (1982). (Eds.). Breeding Plants for Less Favourable Environments, John Wiley \& Sons, New York, p.469.

De-Datta K, Baisakh N, Thet KM, Tu J, Datta SK (2002). Pyramiding transgenes for multiple resistance in rice against bacterial blight, yellow stem borer and sheath blight. Theor. Appl. Genet. 106:1-8.

Donovan C, Wopereis MCS, Guindo D,d Nebie B (1999). Soil fertility management in irrigated rice systems in the Sahel and Savanna regions of West Africa: Part II. Profitability and risk analysis. Field Crops Res. 61:147-162.

Dudal R (1976). Inventory of the major soils of the world with special reference to mineral stress hazards. In: Proceedings of Workshop on Plant Adaptation to Mineral Stress in Problem Soils, 3-14. Beltsville, Maryland. Nov. $22-23$ p.664. 
Edmeades GO, Bänziger M, Beck DL, Chapman SC, Cortes M (1997). Drought and low $\mathrm{N}$ testing networks - past, present and future, in: G.O. Edmeades, et al. (Eds.), Developing Drought and Low NTolerant Maize, March 25-29, 1996. CIMMYT, El Batán, Mexico, D.F. CIMMYT. pp.405-409.

Efisue A, Tongoona P, Derera J, Langyintuo A, Laing M, Ubi B (2008). Farmers' Perceptions on Rice Varieties in Sikasso Region of Mali and their Implications for Rice Breeding. J. Agron. Crop Sci. 194:393-400.

Falconer DS (1989). Introduction to Quantitative Genetics. Third ed. Longman Scientific and Technical, New York, p.438.

Falconer DS, Mackay TFC (1996). Introduction to quantitative genetics. 4th ed. Longman Scientific \& Technical, New York, p.464.

Fasoula AD, Fasoula AV (1997). Gene action and plant breeding. Plant Breeding Rev. 15:315-374.

Fasoula DA, loannides IM, Fasoula VA (1993). A creterion for selecting among entries that considers jointly productivity, stability and heritability Agron. Abstr., p.88.

Fasoula VA, Fasoula DA (2000). Honeycomb Breeding: Principles and Applications, in: J. Janick (Ed.), Plant Breeding Reviews, John Wiley \& Sons, Inc., New York, pp.177-250.

Fawole I, Gerloff GC, Gabelman WH, Nordheim T (1982). Heritability of efficiency in $\mathrm{P}$ utilization in beans (Phaseolus vulgaris L.) grown under P stress. J. Am. Soc. Hortic. Sci. 107(1): 94-97.

Fukai S, Copper M (1995). Review: Development of Drought-Resistant Cultivars using Physio-Morphological Traits in Rice. Field Crops Res., 40:67-86.

Fukai S, Inthapanya P, Blamey FPC, Khunthasuvon S (1999). Genotypic variation in rice grown in low fertile soils and droughtprone, rainfed lowland environments. Field Crops Res. 64:121-130.

Gomez KA, Gomez AA (1884). Statistical procedures for agricultural research. Wiley, Philippines, p.680.

Gregorio GB (2002). Progress in breeding for trace minerals in staple crops. J. Nutr. 132:500S-502S.

Hallauer AR, Miranda FO (1989). Quantitative Genetics in Maize Breeding lowa State University, New Delhi, p.287.

Holland JB, Nyquist WE, Cervantes-Martinez CT (2003). Estimating and Interpreting Heritability for Plant Breeding: An Update, in: J. Janick (Ed.), John Wiley \& Sons, Inc, New York, pp.9-112.

IRRI (2002). Standard Evaluation System for Rice. International Rice Research Institute, Los Banos, Philippines, p.51.

Johnson KF, Robinson HF, Comstock RE (1955). Genotypic and phenotypic correlation in Soybeans and their implications in selection. Agron. J., 47:477-483.

Karim D, Sarkar U, Siddique MNA, Miah MAK, Hasnat MZ (2007). Variability and genetic parameter analysis in aromatic rice. Int. J. Sustainable Crop Prod. 2:15-18.

Kearsey MJ, Pooni HS (1996). The genetical analysis of quantitative traits. Chapman and Hall, London, p.381.

Kimani JM (2010). Genetic studies of Quantitative Quality Traits in Rice Under Low and High soil nitrogen and phosphorous Conditions, and a Survey of Farmer Preferences for Varieties. A thesis submitted in partial fulfilment of the requirements for the degree of Doctor of Philosophy (PhD) in Plant Breeding. African Centre for Crop Improvement $(\mathrm{ACCl})$, School of Agricultural Sciences and Agribusiness, Faculty of Science and Agriculture. University of KwaZuluNatal, Republic of South Africa, p.214.

Kimani JM, Derera J (2009). Combining ability analysis across environments for some traits in dry bean (Phaseolus vulgaris L.) under low and high soil phosphorus conditions. Euphytica, 166(1):1-13.

Kimani JM, Kimani PM, Githiri SM, Kimenju JW (2007). Mode of inheritance of common bean (Phaseolus vulgaris L.) traits for tolerance to low soil phosphorus (P). Euphytica, 155:255-234.
Kirk GJD, George T, Courtois B, Senadhira D (1998). Opportunities to improve phosphorus efficiency and soil fertility in rainfed lowland and upland rice ecosystems. Field Crops Res., 56: 73-92.

Li Z, Pinson SR, Park WD, Paterson AH, Stansel JW (1997). Epistasis for three grain yield components in rice (Oryza sativa L.). Genet. 145:453-65.

Mo A (2009). National Rice Development Strategy (NRDS 2008-2018), p.35.

Nyquist WE (1991). Estimation of Heritability and Prediction of Selection Response in Plant Populations. Crit. Rev. Plant Sci. 10(3):235-322.

Payne RW, Murray DA, Harding SA, Baird DB, Soutar DM (2009). Genstat for Windows (12th Edition) Introduction. VSN International, Hemel Hempstead, p.204.

Pinheiro BDS, Castro EDMD, Guimaraes CM (2006). Sustainability and profitability of aerobic rice production in Brazil. Field Crops Res. 97:34-42.

Poussin J-C, Diallo Y, Legoupil J-C (2006). Improved collective decision-making in action for irrigated rice farmers in the Senegal River Valley. Agric. Syst. 89:299-323.

Presterl T, Seitz G, Landbeck M, Thiemt EM, Schmidt W, Geiger HH (2003). Improving nitrogen-use efficiency in European maize: Estimation of quantitative genetic parameters. Crop Sci. 43:12591264.

Rabiei B, Valizadeh M, Ghareyazie B, Moghaddam M (2004). Evaluation of selection indices for improving rice grain shape. Field Crops Res. 89:359-367.

Roder W, Phengchanh S, Keoboulapha B (1995). Relationships between soil, fallow period, weeds and rice yield in slash-and-burn systems of Laos. Plant Soil 176:27-36.

Rosemary AE, Bibiana MW, Njuguna N, Dominic MK, Daniel A (2010). Rice Value Chain Study Report Fof Kenya. Ministry of Agriculture

(MoA) and Kenya Agricultural research Institute (KARI), p.37.

Saito K, Linquist B, Atlin GN, Phanthaboon K, Shiraiwa T, Horie T (2006). Response of traditional and improved upland rice cultivars to $\mathrm{N}$ and $\mathrm{P}$ fertilizer in northern Laos. Field Crops Res. 96:216-223.

Sarla N, Swamy BPM (2005). Oryza glaberrima: A source for the improvement of Oryza sativa. Curr. Sci. 89:955-963.

Shukla AK, Ladha JK, Singh VK, Dwivedi BS, Balasubramanian V, Gupta RK, Sharma SK, Singh Y, Pathak H, Pandey PS, Padre AT, Yadav RL (2004). Calibrating the Leaf Color Chart for Nitrogen Management in Different Genotypes of Rice and Wheat in a Systems Perspective. Agron. J. 96:1606-1621.

Simmonds NW, Smartt J (1999). Principles of crop improvement. 2nd ed. Cornwall, Blackwell Science Ltd., p. 412.

Singh RK (2005). Heterosis breeding in aromatic rice (Oryza sativa L.) for yield and quality characters. Ind. J. Genet. Plant Breed. 65:176179.

Smaling EMA, Nandwa SM, Janssen BH (1997). In: Replenishing Soil Fertility in Africa. Bursch, R.J. Sanchez, P.A. and Calhoon, F. (Eds.). Soil Science Society of America (SSSA) Special Publication No. 51. Madison, Wisconsin, USA. pp.47-61.

Smith JD, Kinman ML (1965). The use of parent-offspring regression as an estimator of heritability. Crop Sci., 5: 595-596.

Verma OP, Srivastava HK (2004). Genetic component and combining ability analyses in relation to heterosis for yield and associated traits using three diverse rice-growing ecosystems. Field Crops Res. 88:91-102.

WARDA (2006). West African Rice Development Association: NERICA rice for life. Provide article title and page numbers Wissuwa $M, A e N$ (2001). Genotypic variation for tolerance to phosphorus deficiency in rice and the potential for its exploitation in rice improvement. Plant Breed. 120:43-48. 
Wonprasaid S, Khunthasuvon S, Sittisuang P, Fukai S (1996). Performance of contrasting rice cultivars selected for rainfed lowland conditions in relation to soil fertility and water availability. Field Crops Res. 47:267-275.

Wu ZX (2003). The heritability theory of heterosis and its meaning for global agriculture. Yi Chuan Xue Bao, 30:193-200.
Yoji T, Mamum A, Wada T, Kaufman P (Eds.) (1992). Reproductive Adaptation of Rice to Environment Stress. Japan Scientific Societies Press, Tokoyo, p.226. 